\title{
Haze, Hunger, Hesitation: Disaster aid after the 1783 Laki eruption
}

\author{
Claudia E. Wieners * \\ ${ }^{a}$ Institute of Economics, Scuola Superiore Sant'Anna, Pisa, Italy \\ ${ }^{b}$ Centre for Complex Systems Studies, Utrecht University, Netherlands
}

\begin{abstract}
The 1783-1784 Laki eruption was one of the most severe natural catastrophes to occur in Iceland in historical times (since 1140 years). Vegetation damage by sulphate aerosol and fluorine poisoning caused a massive decimation of livestock. The impact of fluorine poisoning and sulphate aerosol on human mortality is uncertain, but the loss of animals caused a famine which took many lives. The vulnerability of the Icelandic society to famine is discussed. 18th Century Iceland was a Danish dependency and, despite the abundance of fish in the surrounding waters, a subsistence farming community and thus highly dependent on livestock. On the other hand, the farming community possessed coping strategies which mitigated the impact of livestock loss. During the famine, the Danish government was in principle willing to provide relief. However, local authorities in Iceland were slow to ask for help, and did not dare to exploit the means at their disposal (e.g. the right to ban the export of Icelandic foodstuff) without consent from Copenhagen. The Danish officials in turn were unwilling to act decisively upon incomplete information. These two factors prevented timely measures. While $4.4 \times 10^{5} \mathrm{~kg}$ of grain were provided for famine relief in summer 1784 , the merchants exported $1.2 \times 10^{6} \mathrm{~kg}$ of fish, which greatly aggravated the hunger in the second winter. The effects of this 'natural' catastrophe could therefore have been significantly reduced by efficient government.
\end{abstract}

\footnotetext{
* Corresponding author

Email address: c.wieners@santannapisa.it (Claudia E. Wieners )
} 
Keywords: Laki, Iceland, volcanic haze, fluorine poisoning, famine, disaster relief

\section{Introduction}

The 1783 Laki eruption was, in terms of lava output, the second largest eruption in Iceland since the country was inhabited around AD870. Lasting from June 8th, 1783 to February 7th 1784, it produced about $15 \mathrm{~km}^{3}$ of lava, 5 covering an area of around $600 \mathrm{~km}^{2}$, spread fine poisonous ash over most of the island, and produced a persistent sulphurous haze which was observed over large parts of the Northern hemisphere (Thordarson \& Self 1993, 2003). The so-called Haze Hardships (Móðuharðindin) caused by the eruption were probably the worst natural catastrophe which befell Iceland, and killed about 1/6 of the human population. However, few, if any, of the deaths were caused directly by the eruption, i.e. by lava streams or tephra fall. Written accounts (e.g. Steingrímsson (1788/1998); Finnsson (1796)) agree that the main causes were famine - brought about by a massive loss of livestock - and non-specified contagious diseases (Hálfdanarson, 1984). More recently, fluorine poisoning and inhalation of volcanic haze have been suggested as additional contributors to human mortality (Grattan et al. 2003; D'Alessandro, 2006; Balkanski et al. 2018). Perhaps remarkably for those times, the government of Denmark - of which Iceland was a dependency - was in principle willing to provide significant famine relief, but on the whole the operation was not successful.

20 In the English literature, this attempted disaster relief, as well as the influence of the socio-economic background state of Iceland, has received relatively little attention. A milestone contribution on the history of the Laki eruption is the Icelandic volume 'Skaftáreldar 1783-1784' (The Skaftá Fires/Laki eruption 1783-1784), which contains research articles and a compilation of historical letters, mostly reports by Icelandic officials to the Danish authorities Gunnlaugsson \& Rafnsson, 1984). However, since its publication in 1984, much research has been done on the geophysical and climatological aspects of the eruption 
(important publications include Thordarson et al. (2003); Thordarson \& Self (2003); Zambri et al. (2019a.b)), its impacts on human health Grattan et al. sо (2003); Schmidt et al. (2010), but also on the socio-economic situation in Iceland (Gunnarsson, 1983; Eggertsson, 1998; Vasey, 2009).

Combining these strands of literature, the current review article discusses how natural and human factors contributed to the high mortality during the Haze Hardships. The following section (exposure) discusses the volcanic hazards and their direct and indirect effects on human health and mortality, especially the contribution by air pollution and fluorine poisoning. Section 3 (vulnerability) outlines the socio-economic situation in Iceland and investigates vulnerability to famine, and section 4 (capability) describes how Icelandic and Danish authorities tried to cope with the disaster. Section 5 summarises possi40 ble long-term effects of the eruption, while section 6 discusses in more general terms the reasons for the meagre effects of relief actions.

Although the article is first and foremost a review on scientific literature, historical sources are used to add some details. Original contributions in this study are the quantification of aid measures in terms of calorie intakes, an estimate of human fluorine intake, and the attempt in the final section to interpret the disaster aid from a risk reduction perspective.

The most important original sources used are: the collection of reports in Gunnlaugsson \& Rafnsson (1984), a collection of laws and regulations for Iceland (Stephensen \& Sigurðsson, 1854), and accounts by the Icelandic parson Jón

so Steingrímsson (Steingrímsson, 1788/1998, 1791/2002) and the student Magnús Stephensen (Stephensen, 1785). The reports in (Gunnlaugsson \& Rafnsson, 1984, p. 299-417) are letters by Icelandic officials to the Danish authorities, and statements by local farmers (pingvitni), sent in 1784. They will henceforth be referred to as [Rep1784]. For a summary of these reports, sorted by topic, see

55 the Supplementary Material (henceforth referred to as SMx, where $\mathrm{x}$ is a section number). 


\section{Hazard exposure: Fire, Fog and Frost}

There already exists an extensive literature on physical aspects of the eruption, including geological, environmental and climatological aspects. These as-

60 quences on the human population, in particular various factors contributing to the high mortality rates, in the light of contemporary records.

\subsection{Environmental impact}

\subsubsection{Local effects: Lava and tephra fall}

65

The eruption took place along a linear vent system of about $27 \mathrm{~km}$ length which is known as Lakagígar (cones of Laki) and is part of the Grímsvötn volcanic system (Thordarson \& Self, 1993). The flood lava eruption started on June 8th, 1783, and consisted of 10 episodes beginning with explosive activity (due to lava degassing) followed by lava flow. The total lava output was estimated to be itself is situated in the uninhabited highlands, lava followed two river gorges into inhabited areas (Steingrímsson, 1788/1998; Thordarson et al., 2003). The first episodes, until about July 20th, occurred on the western part of the vent system and their lava entered the Skaftá river gorge near Hnúta and near Leiðólfsfell 75 (Thordarson \& Self, 1993). The river dried up for 3 months (Thordarson et al., 2003), probably due to evaporation, blocking of the river course, or percolation of water through lava, or a combination of those. The lava followed the river bed to the lowlands, where it spread over the pastures and destroyed several farms. Other farmsteads were destroyed by inundation (after tributaries of the Skaftá became blocked by lava), by tephra fall and by sand storms (partly sand from the exposed beds of the dried-up Skaftá river). From August onward, the eruption shifted to the eastern half of the vent system, and the lava followed the Hverfisfljót river, again destroying several farms. The eruption ceased on February 7th, 1784 .

85

In total, 42 farmsteads and cottages $(\approx 0.8 \%$ of all Icelandic farms) were given up either temporally or permanently directly because of lava flows (19), 


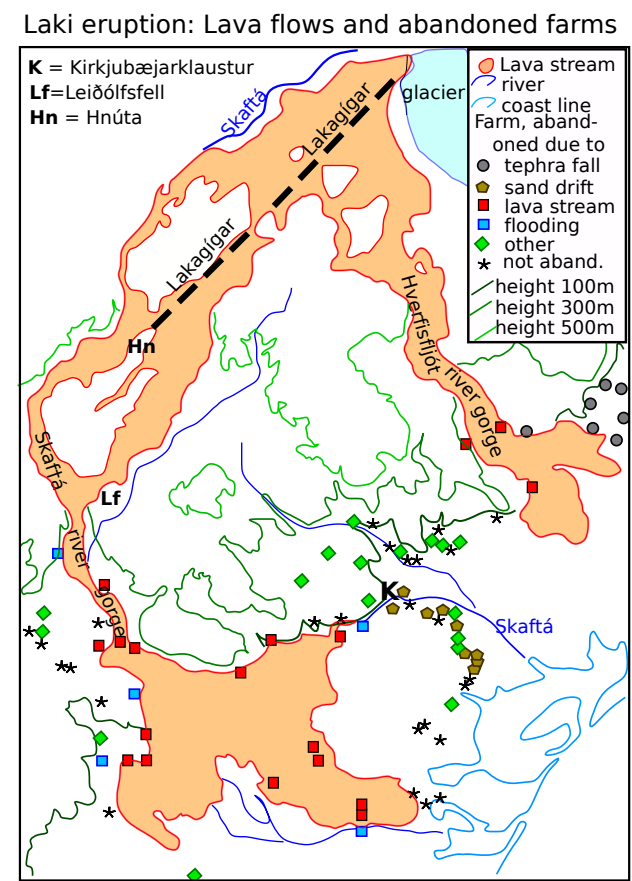

Figure 1: Map of the surroundings of the Lakagígar (based on (Thordarson \& Self, 1993, fig. 7) and (Guðbergsson \& Theodórsson. 1984, chap. 6.3)). 
inundation (5), tephra fall (7) and sand storms (11); another 19 were abandoned for other reasons including loss of animals (Guðbergsson \& Theodórsson, 1984). No human lives were taken by the eruption itself, but several hundred persons had to leave their homes. Some of them stayed in the neighbourhood, e.g. on farms given up by their neighbours, while about 500 out of 1964 inhabitants of Vestur-Skaftafellsýsla left the district, mostly moving west, either to other farms or to the fishing districts, e.g. Vestmannaeyjar, Gullbringusýsla Gunnlaugsson, 1984a). In the two communes closest to the volcano, Leiðvallarhreppur and Kleifahreppur, the number of inhabitants fell from about 1300 in 1783 to 525 in 1784 (Guðbergsson \& Theodórsson, 1984), partly due to migration, partly due to death.

\subsubsection{Distal effects within Iceland: volcanic haze and fine ash}

While the lava was clearly a local hazard, volcanic haze and ash fall affected almost all of Iceland. Only a brief summary will be given; for a thorough assessment including a compilation of translated contemporary observations, see Thordarson (1995). For a map showing districts (sýslur; singular sýsla), see fig. 2

The Lakagígar magma was rich in gas, including SO2, which reacts in the atmosphere to form droplets of sulphuric acid (H2SO4) (Stevenson et al. 2003), which led to the formation of a thick, "dry", acidic haze. It was estimated that roughly $120 \mathrm{Mt}$ of SO2 were emitted, of which about $80 \%$ were carried by eruption columns into the high troposphere and lower stratosphere $(9-13 \mathrm{~km}$ height) (Thordarson \& Self, 2003), while about 20\% slowly degassed from the lava streams. The latter part of the emission mainly affected southern Iceland, while the former spread widely, transported by high-level winds, and was reintroduced to the lower troposphere by subsidence. In particular, northern Iceland was hit by three waves of strong haze which arrived with northerly, rather than southerly, winds, suggesting that the haze was first transported 115 northward at high altitude, before subsiding and being transported back south at lower levels (Thordarson, 1995). 


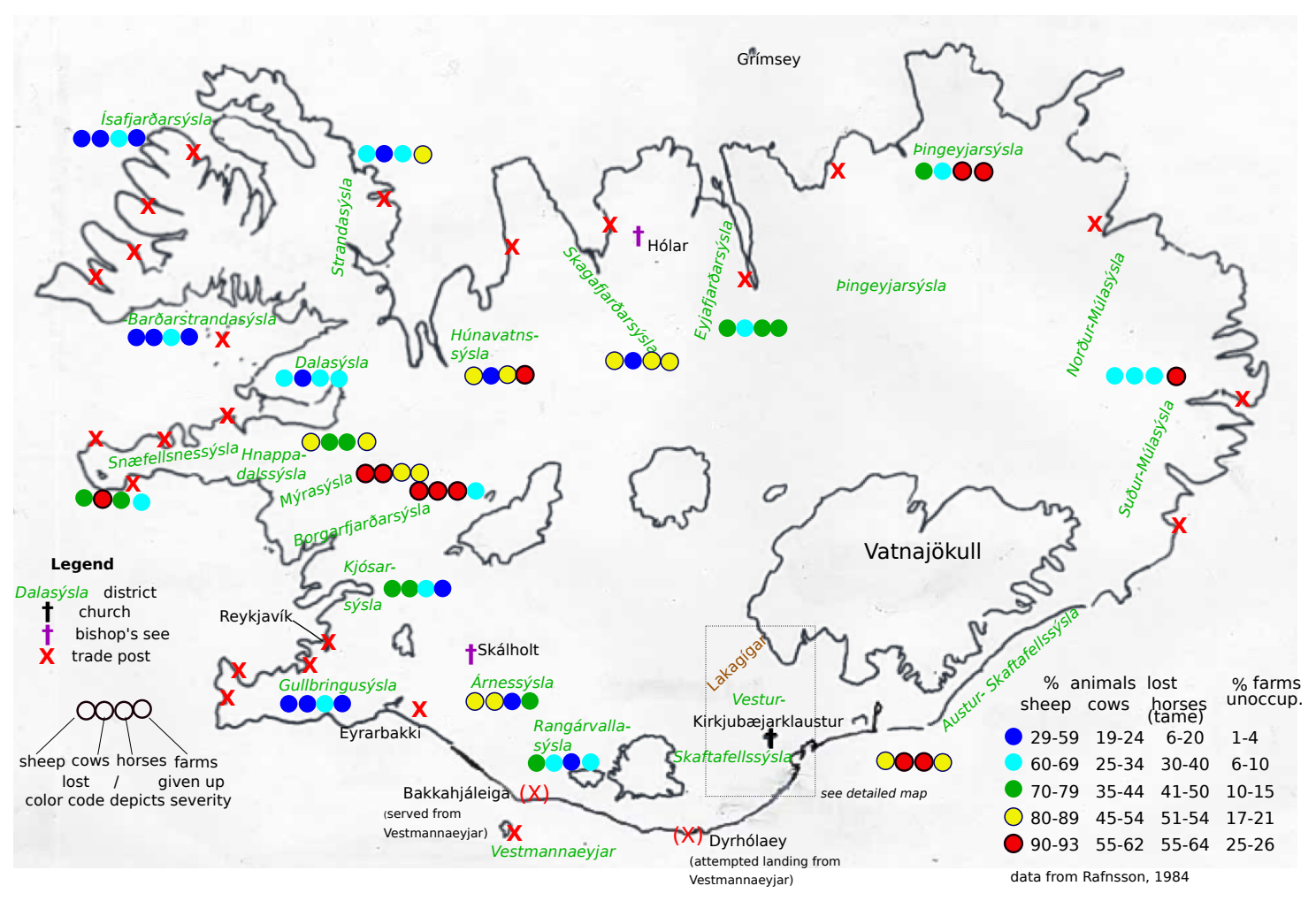

Figure 2: Overview map of Iceland, with districts, trade posts in 1783 (data from Gunnarsson (1983)), and livestock loss and abandoned farms (data from Rafnsson (1984a)). Livestock loss is given as $\left(N_{0}-N_{1785}\right) / N_{0} \times 100 \%$ where $N_{1785}$ is the number of animals in 1785 and $N_{0}=\left(N_{1703}+N_{1795}\right) / 2$. The fraction of abandoned farms is the number of abandoned farms plus cots divided by the total number of farms and cots in 1785 (in Gullbringu-, Kjósar- and Snæfellsnessýsla, only farms are included). Note that Vestur-and Austurskaftafellssýsla are treated as one unit; same for Norður- and Suður-Múlasýsla. 
The haze was associated with 'sulphur dust' (deposition of sulphur compounds) and severe damage to the vegetation. Grass whitened, withered to the roots (Steingrímsson, 1788/1998). Grass growth, and hence the hay harvest, was leased at the vents (Thordarson \& Self 1996). Fluorine can be adsorbed on fine ash particles but is subsequently washed into the ground by rainfall. Comparison 
with measurements from the 1970 Hekla eruption suggests a fluorine deposition by fine ash of about $9 \times 10^{7} \mathrm{~kg}$ which, when spread over an area of $200000 \mathrm{~km}^{2}$, yields $450 \mathrm{mg} / \mathrm{m}^{2}$ (Thordarson \& Self, 2003) ${ }^{1}$ Assuming a probably optimistic hay crop of $1000 \mathrm{~kg} / \mathrm{ha}$ (Friðriksson, 1972) yields a deposition of $3000 \mathrm{mg} / \mathrm{kg}$ of hay, although instantaneous concentrations were probably less, because the fluorine was deposited over several months, and meanwhile dilution by rain water or permanent adsorption to the soil (Thorarinsson, 2012; D'Alessandro, 2006) could reduce concentrations. Still, for a sheep weighing $75 \mathrm{~kg}$ and consuming the equivalent of 3kg of dried grass/day (Sigurdarson \& Pálsson, 1957), fluorine intake may have been well above $15 \mathrm{mg} / \mathrm{day} / \mathrm{kg}$ (bodyweight), which experiments by (Roholm, 1937, Ch. XXI-XXIV) suggest as an estimate for the lethal dose over periods of half a year (see also sect. 2.2.3.

Livestock was severely affected by the eruption, both through lack of fodder and through fluorine poisoning. A drop in milk production to one-half or even nothing was noticed immediately after the arrival of the haze, in VesturSkaftárfellssýsla (Steingrímsson, 1788/1998), but also in the North (see SM3), where the milk yield did not suffice to feed the people, let alone to set aside winter stores. Symptoms associated with fluorine poisoning of livestock (including feebleness, swellings, softened bones, loss of hair) were reported from nearly all over Iceland, except in the northwest (Pétursson et al., 1984), consistent with the spread of fine ash (Thordarson \& Self, 2003; Thordarson, 1995) Tooth deformations called gaddur (spike) were observed from autumn 1784 onwards and could occur even years later (Finnsson, 1796). Gas poisoning or inhalation of ash particles may have added to the symptoms (Pétursson et al., 1984). Animals, especially sheep, started to die within two weeks after the onset of the eruption in nearby parishes (Steingrímsson, 1788/1998); elsewhere it took several month for livestock to die (Pétursson et al., 1984). In many regions, animals starved or had to be culled for lack of hay, and in some cases to provide meat for humans, e.g. in Pingeyjarsýsla (see SM2,3).

\footnotetext{
${ }^{1}$ Thordarson \& Self (2003) give $500 \mathrm{mg} / \mathrm{km}^{2}$, which seems to entail a typo in the unit.
} 
Rafnsson (1984a) compared the number $\mathrm{N}$ of surviving farming animals in 1785 to 'normal' (i.e. the mean of 1703 and 1795), and found a reduction by about $1 / 2$ for cattle and horses and $3 / 4$ for sheep (see table 1 and fig. 2). Apart from the impact of the eruption, this loss also reflects the impact of the previous cold summer 1782, which caused lack of hay and culling of animals in the north and east (Guðjónsson, 2010, Tv_Eyjafjarðar_Dec83)], especially in the northeastern corner of Pingeyjarsýsla (Guðjónsson, 2010), and the effect of the frozen grounds and wet summer weather (especially in the south and west) in 1784, which again led to an insufficient hay harvest and further loss of animals (Guðjónsson, 2010). Incomplete recovery by 1795 can lead to a, possibly regionally dependent, underestimate of the actual loss. The loss of animals was greatest close to the volcano (Vestur-and Austur-Skaftafellssýsla), but also some districts of the west (see fig. 2), while the extreme northwest and southwest were less affected. Within Árnes- and Rangárvallasýsla (Pétursson et al., 1984) and in the north (Thordarson, 1995), inland communes were in general more strongly affected, which may be due to a dominantly northwestward dispersal of the ash and decreasing concentrations away from the source (Pétursson et al., 1984). In coastal regions, animals fared better when fed with seaweed (Steingrímsson, 1788/1998, SM3).

Wild animals, such as fresh water fish and birds, were also reduced (Steingrímsson, 1788/1998; Pétursson et al., 1984), while there is no indication that marine fish was affected.

\subsubsection{Pollution outside Iceland and impact on climate}

The transport of sulphuric haze was analysed by Thordarson (1995); Thordarson \& Self (2003). The haze likely covered the northern hemisphere north of $35^{\circ}$. A thin haze, transported at high altitude by the jet stream, was first noted in central and west Europe around the 17th of June. Six days later, a high pressure system with centre over the Netherlands caused subsidence and introduced large quantities of haze into the lower troposphere. Thick dry mist and sulphur stench were widely observed and debated (Thordarson, 1995; Grattan 


\begin{tabular}{|c||c|c|c|}
\hline & 1703 & $1785(\%$ of 1703$)$ & 1795 \\
\hline \hline Cattle (total) & 35860 & $16592(46 \%)$ & 22488 \\
\hline Cows & 24467 & $12898(53 \%)$ & 15497 \\
\hline Sheep (total) & 278994 & $64459(23 \%)$ & 241171 \\
\hline Ewes & 167937 & $43895(26 \%)$ & 139125 \\
\hline Horses & 26909 & $12786(48 \%)$ & 22599 \\
\hline
\end{tabular}

Table 1: Number of farming animals in Iceland before, 2 years after, and 12 years after the Laki eruption. Based on data from Rafnsson (1984a).

\& Brayshay, 1996; Halldórsson, 2013), as the news about the Icelandic eruption only reached the outside world by the end of August. The sulphuric haze caused damage to plant leaves (Grattan \& Brayshay, 1996), but no wide-spread harvest failures (Halldórsson, 2013, p. 85 ff). Thick low-altitude haze was present, on and off, until the end of July, and pulses of high intensity occurred through autumn, while the high-altitude (upper troposphere/lower stratosphere) haze remained till early 1784 (Thordarson \& Self, 2003).

The Laki eruption was followed by large-scale weather anomalies, including 215 a hot summer in central Europe in 1783, a cold winter in Europe and North America in 1783/84, northern hemispheric cooling for about 3 years (Thordarson, 1995; Thordarson \& Self, 2003), and drought in the Nile catchment (Oman et al., 2006a). Several modelling studies have investigated the dispersal and climatic effect of the Laki haze (Stevenson et al., 2003; Highwood \& Stevenson, 2003; Oman et al., 2006a; Chenet et al., 2005; Oman et al. 2006b; Schmidt et al., 2010; Pausata et al., 2011; Zambri et al., 2019a,b). The studies reproduce a strong sulphate aerosol haze in the northern hemisphere, both near the surface and in the upper troposphere/lower stratosphere, lasting for several months. Zambri et al. (2019a) showed that some aerosol may have reached the southern hemisphere. The haze lead to a negative radiative forcing anomaly over the northern hemisphere, with peak values for late summer $1783:-5.5 \mathrm{~W} / \mathrm{m}^{2}$ over the northern hemisphere (Highwood \& Stevenson, 2003), $-4 W / m^{2}$ global mean 
(Oman et al., 2006b), $-12 W / m^{2}$ over the northern hemisphere, (Zambri et al., 2019b). It cooled the northern hemisphere for several months; peak values for on 55 days in June-September 1783 (peak value: 113ppbv), but on 0 days in France.

Sulphate aerosol mostly forms particulate matter of diameter $<2.5 \mu \mathrm{m}$ 
(PM2.5). Oman et al. (2006b) finds a sulphate concentration of $8-20 \mu \mathrm{g} / \mathrm{m}^{3}$ at $65^{\circ} \mathrm{N}$, averaged over June-August and $30^{\circ} \mathrm{W}-45^{\circ} \mathrm{E}$, while the largest values in Chenet et al. $(2005)$ are $\approx 400 \mu \mathrm{g} / \mathrm{m}^{3}$ near Iceland and $\approx 40 \mu \mathrm{g} / \mathrm{m}^{3}$ in northwest Europe, though these may be overestimates as the study assumes a complete conversion of SO2 to sulphate aerosol. Balkanski et al. (2018) model PM2.5 concentrations in June-September 1783 and obtain for Iceland an average daily mean of $34 \mu \mathrm{g} / \mathrm{m}^{3}$ and a highest daily mean of $148 \mu \mathrm{g} / \mathrm{m}^{3}$; the highest corresponding values in France are $3.1 \mu \mathrm{g} / \mathrm{m}^{3}$ and $70 \mu \mathrm{g} / \mathrm{m}^{3}$ (in Nancy). A threshold of $20 \mu \mathrm{g} / \mathrm{m}^{3}$ is crossed in Iceland on 70 days within June-September 1783, and in France on up to 3 days. The US health guidelines for PM2.5 (International Volcanic Health Hazard Network (IVHHN)) are a maximum concentration of $27065 \mu \mathrm{g} / \mathrm{m}^{3}$ as daily mean and $15 \mu \mathrm{g} / \mathrm{m}^{3}$ as annual mean. However, Schmidt et al. (2011) find that a Laki-style eruption in present-day conditions would increase the mean PM2.5 concentrations over the first 3 months after the eruption by $>100 \mu \mathrm{g} / \mathrm{m}^{3}$ in the south of Iceland, $50-100 \mu \mathrm{g} / \mathrm{m}^{3}$ in the rest of the country, $20-30 \mu \mathrm{g} / \mathrm{m}^{3}$ for England and $10-20 \mu \mathrm{g} / \mathrm{m}^{3}$ in France, i.e. a stronger 275 effect than the results in Balkanski et al. (2018) (unless industrial and volcanic contributions interact nonlinearly).

\subsection{Human mortality}

The contemporary treatise by bishop Hannes Finnsson (1796) considers hunger and contagious diseases the main drivers for human mortality after the eruption. More recently, inhalation of gas and acid aerosol as well as fluorine poisoning have been suggested as significant contributors (D'Alessandro, 2006). Gas and aerosol have also been suggested to have caused excess mortality in Europe (Grattan et al., 2003, 2005; Schmidt et al., 2011; Balkanski et al., 2018).

After outlining the temporal and spatial patterns of mortality, I argue that, while hunger and disease alone could explain these data, the influence of pollution remains uncertain. 


\begin{tabular}{|c|c|c|c|c|c|c|}
\hline year & 1782 & 1783 & 1784 & 1785 & 1786 & 1787 \\
\hline \hline population & 48736 & 48925 & 44600 & 39578 & 38368 & 38668 \\
\hline deaths & 1231 & 1227 & 5429 & 5649 & 2128 & 920 \\
\hline births & 1229 & 1371 & 1104 & 602 & 937 & 1220 \\
\hline
\end{tabular}

Table 2: Population, deaths and births in Iceland, 1783-87. Population is given for the end of the corresponding year. Data from Hálfdanarson (1984).

\subsubsection{Mortality data}

The number of deaths in Iceland was above normal for 1784-86, especially in the first two years (see tab. 2), but not in 1783. Excess mortality in 1786 can be explained by a smallpox epidemic that started in November 1785 and killed 1500 persons, of which 74 died in 1785, (Finnsson, 1796). It cannot be attributed to the eruption, since smallpox epidemics were common in the 18th century, so we focus only on the period up to 1785. The average death rate for 1778-1782 was 30/1000 (Gunnarsson, 1983), amounting to roughly 1500 persons/year. In 178485, 11078 persons died. Subtracting the 74 smallpox cases and the estimated normal deaths (1500 per year) gives 8004 excess deaths (about $16.5 \%$ of the 1783 population) that may have been caused by the eruption. Population decrease was aggravated by a reduction of births, particularly in 1785-86.

For understanding the role of air pollution, it is relevant whether any unusual mortality can be detected in the second half of 1783 , even if not visible in the national, annual mean. Pingeyjarsýsla suffered the highest mortality anomaly in 1783 , namely $150 \%$ of the $1778-82$ mean (see fig. 3); but elevated mortality there might also be related to the harsh winter 1782-83 (Guðjónsson, 2010), which is reported to have caused death and migration in the north of Pingeyjarsýsla (see SM6). Vasey (1991) analysed 65 parishes for which monthly resolution data was available. For those parishes where data was available for 1783 (the southwest-west and the north), mortality in any month of this year is much lower than peak levels in 1784 and 1785. Mortality in the second half of 1783 

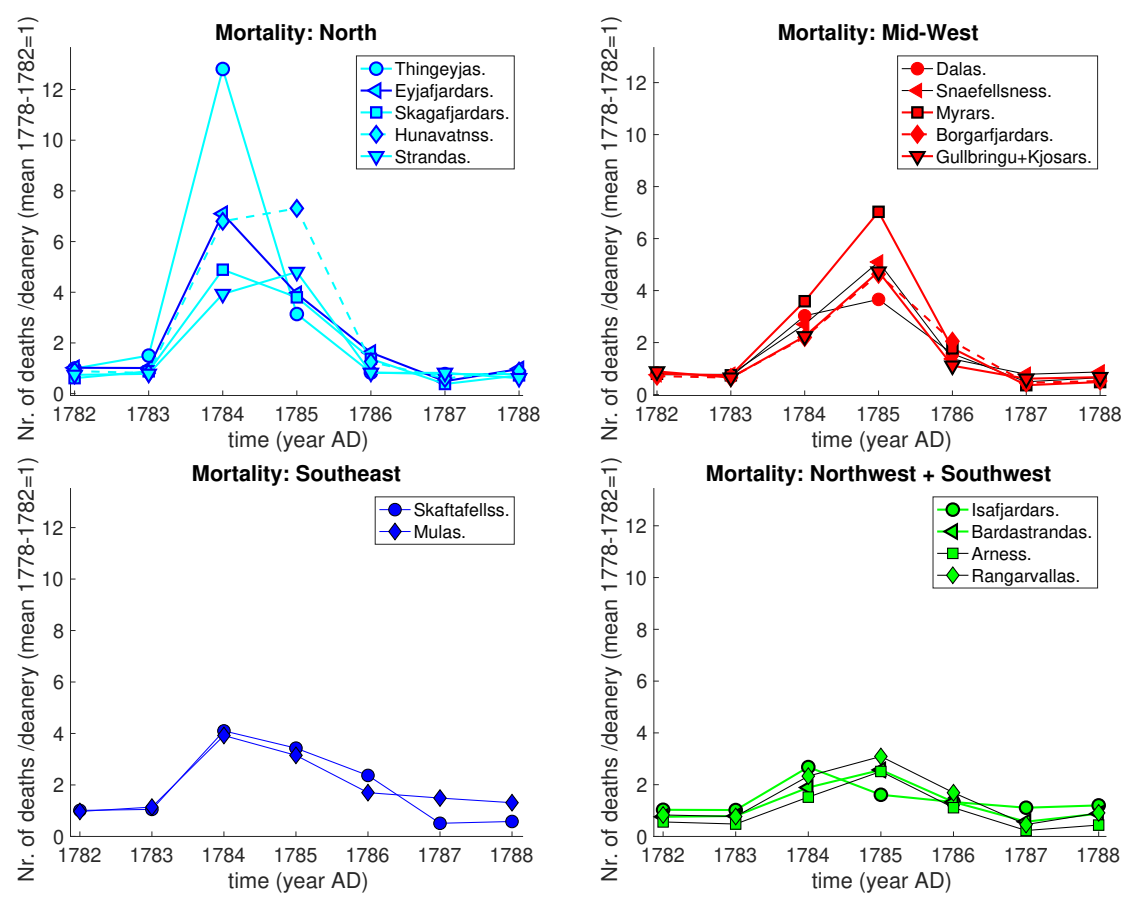

Figure 3: Number of deaths in Iceland, 1782-1788, per deanery, with the mean over 17781782 being normalised to 1 . Over whole Iceland, the mean over those years was 30 deaths per 1000 inhabitants (Gunnarsson, 1983). Deaneries were roughly equivalent to the districts shown in fig. 2, although sometimes two districts form one deanery (e.g. Vestur- and Austur-Skaftafellssýsla, Norður- and Suður-Múlasýsla). Plots based on data from Hálfdanarson (1984). 
was $18 \%$ higher than in the first hal: ${ }^{2}$. In normal years (average over the four written record from Kirkjubæjarklaustur (Steingrímsson, 1788/1998, p.78-79) mentions that mortality in 1783 was not great, but surged after new year 1784;

\footnotetext{
${ }^{2}$ Unfortunately, Vasey only gives fractions of the total over 1783-86, not absolute numbers of deaths. The absolute numbers were estimated by assuming the largest common factor (up to rounding errors) to represent one person.

${ }^{3}$ This was tested by comparing the true data to 100000 surrogate data sets, in which 42 deaths are distributed randomly over 12 months with the same probability as Vasey's faminefree decades
} 
in Pingeyjarsýsla 'people began to die from hunger shortly after new year and continued to die the whole winter, spring and until now [Sept. 16th, 1784], though less widely in the last two months' see SM6. Conceptions (births - 9 months) were below normal from the beginning of 1784 through the first half of 1785 (Vasey, 1991), supporting the notion of severe hardships from winter $1783 / 84$ onwards.

340

Investigating mortality in 1784-85, Hálfdanarson (1984) divided Iceland in four regions, 'north', 'mid-west', 'northwest and southwest', and 'southeast' (see fig. 3) and assessed seasonality of deaths, based on monthly data from 26 parishes ( $8 \%$ of the Icelandic population). The north suffered very high mortality in 1784 (3.9-12.8 times as high as normal) and high (3.1-7.3 times normal) mortality in 1785; in both years, mortality peaked in spring, the season of lowest food supply. The west experienced moderately elevated mortality in 1784 (2.23.6 times normal) and high mortality in 1785 (3.7-7.0 times normal); no peak occurred in 1784 , but mortality increases through summer and autumn to peak in winter-spring 1785 . In the northwest and southwest, overall mortality was lowest (1.5-2.7 and 1.6-3.1 times normal in 1784 and 1785, respectively), with a maximum in late 1784 /early 1785 . In the southeast, mortality was somewhat higher (3.9-4.1 and 3.2-3.4 times normal), with no seasonal data. Vasey (1991) with his larger data set (65 parishes) broadly confirms the seasonal patterns and finds that spring peaks in 1784 and 1785 were also present in Norður- and Suðurmúlasýsla. It should be noted that the data provide the location of death, not the origin of a person: A fugitive dying in a foreign district would be listed in that district. The population loss in the hardest-hit districts is therefore likely underestimated.

Outside Iceland, excess mortality was observed at least in France and England in summer 1783-summer 1784. For France, Grattan et al. (2005) found a 38\% increase above normal levels of mortality in August-October 1783 in 53 parishes, but no strong increase in June and July. Balkanski et al. (2018), using an extended data set, find an increase of $32 \%$ for June-September, without specifying monthly resolution. Grattan et al. (2003); Witham \& Oppenheimer (2004) 

near-average mortality in June and July 1783, but a strong rise in August (127\% of the normal value) and September $(158 \%)^{4}$ Mortality remained somewhat elevated over the next months and peaked again in January-February 1784; this second peak might be attributed to the severe winter (Witham \& Oppenheimer,

\subsubsection{Hunger and contagious disease}

In the parishes analysed by Hálfdanarson (1984), 959 deaths occurred on 1784-85. Of these, 174 were attributed to hunger and 233 to 'landfarsótt', which literally means 'land-travelling disease' and seems to have been used rather undiscriminatively for many endemic, contagious diseases, but not distinct epidemics like smallpox (Hálfdanarson, 1984). Other causes of death include hunger-sensitive diseases like scurvy (11 cases), diarrhea (26), but also accidents, old age, and infant mortality. 341 deaths are marked as 'other and unknown'. In the north, hunger was the most frequent attributed cause of death, and landfarsótt occurred relatively scarcely. In the west, both hunger and landfarsótt were common, while in the northwest and southwest, only one case of starvation was recorded, but landfarsótt did occur.

Hunger as main cause of death in the north would be consistent with the fact that mortality peaked not immediately after the eruption, but in spring, when food was used up. Although the milk production dropped dramatically with the arrival of the haze, Danish grain, fish, moss, and the meat of culled animals provided some food for the first few months (see SM6).

Landfarsótt raged mostly in autumn 1784 and spring 1785 and was most prevalent in the west. The connection between landfarsótt and hunger is subtle. As Hálfdanarson (1984) point out, they not only have different temporal and

\footnotetext{
${ }^{4}$ Grattan et al. (2003) gives $169 \%$ of the normal mortality for July-September 1783 in table 2 and the main text. However, this is inconsistent with the monthly values in the same table, which indicate a value of $128 \%$. This value does appear in their fig. 2 .
} 
spatial patterns, but landfarsótt attacked all social strata, whereas hunger especially affected the poorest (vagabonds, paupers, farmhands), and landfarsótt especially killed the very young and the elderly, while hunger deaths were more evenly distributed over all age groups. Thus, landfarsótt was probably not merely deficiency diseases connected to malnutrition (such as scurvy).

On the other hand, it is known that during famines seemingly unrelated (endemic) diseases also surge, due to impaired immune resistance or indirect factors, such migration and deteriorating sanitary conditions, and these diseases may also attack those with sufficient resources to avoid starvation (Ó Gráda 2007). Even though starvation was not frequent in the west of Iceland in spring 1784, people suffered hardships. For example, the district commissioner Jón Arnórsson of Snæfellssýsla, a district in western Iceland with good fishing grounds and some farms, wrote that the district had lost considerable amounts of livestock and 45 farms had been given up as farmers fled to the coast to save their life by fishing (see SM8). The fishermen also suffered, because they could not exchange part of their catch for farming products (butter, wool) and had to live on fish alone. A second problem in Snæfellssýsla was the fugitives from northern and southeastern Iceland who flocked to the fishing districts - "a few hundred poor people [...] of both sexes and all age groups, no small burden 410 to this district [Snæfellssýsla]" (Rep1784; SM8) - probably leading to cramped accommodation, which together with the generally poor and unhygienic housing (Magnússon, 2010, p 48ff) may have facilitated the spreading of diseases. It is therefore possible that the famine was the main driver of landfarsótt.

Regional differences in animal loss (see fig. 2) were an important, but not the only factor in determining human mortality. Animal loss, and loss of milk production in summer 1783 was very high in the Skaftafellssýslur (Steingrímsson, 1788/1998), where recorded mortality was not particularly high. However, persons that fled these districts and died elsewhere do not appear in this count. For the region closest to the eruption (Fljótshverfi, Síða, Landbrot), the death toll including fugitives was high: 224 out of 602 former inhabitants (37\%) died (Steingrímsson, 1788/1998; Pétursson et al., 1984). The very high death toll in 
the north cannot solely be explained by the loss of animals, which was high, but not exceptionally high. Additional factors might include a stronger drop in milk production in summer-autumn 1783 and the cold winter 1782-83, which had exhausted hay and food reserves and already killed some animals (see SM2,3,6), so that low milk yield per animal and low number of animals coincided in the north. Poor access to alternative sources of food, in particular fisheries Gunnarsson (1980); Ogilvie \& Jónsdóttir (2000), may have contributed as well. A higher human exposure to pollutants has also been suggested Schmidt et al. (2011). The mid-west region (Kjósar- to Snæfellssýsla) experienced high losses of livestock, but mortality, only surged from autumn 1784 onwards, i.e. there was no wide-spread starvation in spring 1784 as in the north, possibly because of milder winter weather in 1782-83 and better fishing [SM1,4]. As outlined above, disease played a significant role in the west after summer 1784 .

Three regions experienced a relatively minor loss of sheep and cows: the northwest, Gullbringusýsla and Norður- and Suður-Múlasýsla. Of these, the northwest suffered little human mortality, with the exception of Strandarsýsla. The high fraction of abandoned farms in that district (see fig. 2) might partly be due to the proximity of the fishing districts which enabled migration. In

440 Gullbringusýsla, mortality in 1785 was significantly higher than in the northwest (except Strandarsýsla). Both hunger and landfarsótt did occur (51 and 95 deaths, respectively, in the Hvalsnes living (Hálfdanarson, 1984)). The district received a considerable number of fugitives (see SM8), including 148 from Vestur-Skaftafellssýsla Gunnlaugsson (1984a), and 61 out of 166 deaths in Hvalsnes in 1785 were from outside the region (Hálfdanarson, 1984). Thus fugitives increased the mortality statistics, both directly (by dying in the district) and possibly indirectly (competing for fish and good from the trade posts, see SM7,8). In Norður- and Suður-Múlasýsla, Vasey (1991) finds that mortality peaked in spring 1784 and spring 1785, suggesting hunger as a main driver, despite the relatively modest loss of animals. The number of abandoned farms was the highest in Iceland $(25.7 \%)$, possibly in part due to migration. Like the north, Norður- and Suður-Múlasýsla had experienced a harsh winter in 1782-83 
and had poor access to fishing.

Hunger and disease as main driver of excess mortality could explain the that they actually were the only significant drivers. $36 \%$ of the deaths in 1784 85 in Hálfdanarson (1984) are ascribed to 'other and unknown' causes. This could be due to incomplete record keeping, but also due to distinct additional drivers of human mortality that were not recognised at that time, for example, fluorine poisoning and air pollution. The fact that the social status of 228 out of 959 deaths is 'other and unknown' might suggest that record keeping was indeed not complete, but this may not explain all 'unknown' deaths.

\subsubsection{Fluorine poisoning}

Although fluorosis in humans due to volcanic eruptions is uncommon, it has been suggested that fluorine poisoning occurred after the Laki eruption (D'Alessandro, 2006).

Humans might have inhaled fluorine or ingested it in water or food. Fluorine poisoning would likely have occurred with a delay at least as long as in case of the grazing animals, i.e. several months except close to the volcano, which would be consistent with the timing of mortality. There are several reports that humans suffered diseases resembling those observed in livestock. The farmers in Pingeyjarsýsla, after describing the 'bone sickness' (fluorosis) in animals, report that humans also displayed symptoms, in particular, feebleness and swellings, and some died from it (see SM5). Some witnesses say that it is difficult to decide whether 'bone sickness' or hunger were the causes. The district commissioners in Mýrarsýsla and Borgarfjarðarsýsla state that humans suffered of 'an unusually severe scurvy' that had 'attacked nerves and bones and here and there killed persons. The same illness, but still more severe, has attacked the animals...' (see SM5).

The connection between scurvy and fluorosis is interesting. Sheep, cattle and horses are not susceptible to scurvy, as these animals produce their own vitamin C. The fact that the quoted letters and Finnsson (1796) consider scurvy 
as a possible disease in animals indicates that scurvy and fluorosis were easy to confuse. In the detailed descriptions by (Steingrímsson, 1788/1998, p. 77caused strong symptoms but was generally not lethal within $1 / 2$ year (with the exception of 1 pig that died on day 171). So $15 \mathrm{mg} / \mathrm{day} / \mathrm{kg}$ may serve as an estimate for the lethal dose of fluorine for $1 / 2$ year; for a human weighing 
$50 \mathrm{~kg}$, this equals $0.75 \mathrm{~g} / \mathrm{day}$. As an estimate for the lower limit of fluorine for 10 years or more can cause skeletal fluorosis, and Sigurdarson \& Pálsson (1957) found that $20-40 \mathrm{mg} /$ day of fluorine for $1 / 2$ year caused mild fluorosis (slight bone changes) in sheep. As sheep have a similar body weight to humans, $20 \mathrm{mg} /$ day for $1 / 2$ year will be used as an estimated threshold for mild fluorosis.

Fluorine could have been inhaled, either as HF gas or in fine ash, or ingested with drinking water, meat or plant-based food. I aim to give generous upper estimates of these processes in distal areas, acknowledging that exposure close to the volcano may have been higher. HF concentration in distal volcanic plumes is generally far below health guidelines (International Volcanic Health Hazard 525 Network (IVHHN)) and therefore seems an insignificant source of fluorine. Fine ash can be inhaled while it is falling, but also when it is resuspended by wind. After the Eyjafjallajökull eruption, Thorsteinsson et al. (2012) found PM10 concentrations of up to $1230 \mu \mathrm{g} / \mathrm{m}^{3}$ (24h mean) in nearby Vík. Ash concentrations in distal areas after the Laki eruption were probably much lower, because only a sub-millimeter ash layer was locally available for resuspension. Humans inhale about $10 \mathrm{~m}^{3} /$ day of air, which would amount to $12.3 \mathrm{mg}$ of fine dust inhaled. Allowing for the possibility that some particles up to $100 \mu \mathrm{m}$ could be inhaled and provide fluorine (even if intercepted in the upper airways) could quadruple the amount of dust, if the grain size distribution in Thorsteinsson et al. (2012) is representative also for Laki ash. But $50 \mathrm{mg}$ is still much less than the estimated lethal dose of fluorine, even if the particles had consisted entirely of fluorine.

Surface water was found to contain 1-9.5ppm of fluorine after a Hekla eruption covering the area with $1-10 \mathrm{~cm}$ of coarse tephra of a fluorine content of 70-110ppm. Laki tephra was estimated to be richer in fluorine (500ppm, Thordarson \& Self (2003)), but the ash layer in distal areas was much thinner and the ashfall spread over a longer time, so 10ppm (10mg/l) seems a generous upper estimate. Milk would have been safe to drink, as fluorine does not penetrate into it (Pétursson et al., 1984). The fluorine content of meat is more difficult to estimate. (Roholm, 1937, p.44) found that the ash of bones of sheep that 
had grazed near Hekla during the 1845 eruption contained up to $20 \mathrm{~g} / \mathrm{kg}$ of fluorine. In healthy humans, bones contain $99 \%$ of the body's fluorine Zohori \& R.M., 2009). Assuming this to hold also for sheep that died of chronic fluorosis, and assuming bones to account for $15 \%$ of the body weight (I pessimistically ignore the fact that bone ash weighs less than bone) yields $40 \mathrm{mg} / \mathrm{kg}$ fluorine in the rest of the sheep's body. So a daily consumption of 31 water and as much as $1 \mathrm{~kg}$ of meat $(30 \mathrm{mg}+40 \mathrm{mg}=70 \mathrm{mg}$ of fluorine) seems unlikely to cause lethal fluorosis. However, one potentially significant source of fluorine is Iceland moss (cetraria islandica). Although the harvest was severely reduced by the eruption (see SM2,6) some people in Eyjafjarðarsýsla tried to live on 'moss and water' in the summer 1783 (see SM,6). Like grass, the moss could have contained a large amount of fluorine. It is difficult to find nutritional information on Iceland moss, but traditionally, 2 barrels of moss were considered equivalent to 1 barrel of flour (Svanberg \& Egisson, 2012), of which 500g might serve as a meagre daily ration, so $1 \mathrm{~kg}$ of moss a day might be a reasonable estimate. According to (Rogers, 2012, p.455), 1750kg of dried moss can be harvested per hectar, so $1 \mathrm{~kg}$ of moss would require about $6 \mathrm{~m}^{2}$, maybe more since the eruption had reduced the yield. With the estimates from sect. 2.1.2, one sheep would have grazed $30 m^{2}$ per day. So, depending on harvesting and preparation techniques, the fluorine intake of a person trying to live on moss might have been of a similar magnitude, maybe somewhat lower, than that of grazing sheep. However, one can doubt whether many farmers could harvest enough moss to live on it for a sufficiently long period to contract lethal fluorosis; by autumn, the farmers on Eyjafjarðarsýsla were subsisting on meat and spoilt grain from the trade post (see SM6). These tentative estimates suggest that (mild) fluorosis in humans was quite possible, while a major contribution of lethal fluorosis to the mortality crisis of $1784-85$ seems doubtful.

Gestsdóttir et al. (2006) performed test excavations on two cemeteries in Vestur-Skaftafellsýsla, Búland and Eystri-Ásar to investigate human bone remains for traces of fluorosis. Only one exhumed skeleton had buried between 575 1784 and 1845 and may therefore have been affected by the Laki eruption. No 
signs of fluorosis were found in that skeleton, thus the result remains inconclusive.

\subsubsection{Gas and aerosol}

The modelling results discussed in 2.1.3 suggest that health standards for

SO2 and PM2.5 (particulate matter smaller than 2.5 $\mu \mathrm{m}$ ) from sulphate aerosol were exceeded in Iceland and probably also in Europe. Symptoms consistent with high SO2 and sulphate aerosol concentrations were reported in Iceland and Europe. Reverend Jón Steingrímsson, whose parish was closest to the volcano, mentions respiratory disorders such as difficult breathing, especially with persons suffering from pre-existing chest diseases, and irritated throats, skin and eyes (Steingrímsson, 1788/1998, p. 41). Breathing problems in that region persisted at least through spring 1784, possibly due to continuing outgassing from the lava streams. However, Jón Steingrímsson explicitly states that no sudden deaths or mortal illness arose from the bad air (Steingrímsson, 1788/1998, p. 89) in 1783.

The high death rates in north Iceland (a region with high pollution exposure) have been interpreted as indication for a direct contribution of air pollution to human mortality 1783-85 (Schmidt et al., 2011). Respiratory symptoms were recorded in a document from Grund, Eyjafjarðarsýsla (cited in (Thordarson, 1995)). The pingvitni (farmers' statements) in Eyjafjarðarsýsla, Dec. 1783, reported 'disgusting stench and ill odour, such that men with [pre-existing] breast diseases temporarily stayed in bed' (see also SM5). None of these documents, nor any of the letters in [Rep1784], mention any deaths directly connected to these symptoms, or any mysterious increase in mortality in summer-autumn 1783. The overwhelming concern in the pingvitni from Eyjafjarðarsýsla is imminent famine. As outlined above, greater food scarcity can also explain the high death rates in the north. Of course, contemporaries could have misdiagnosed or overlooked deaths by air pollution.

In Europe, symptoms indicating health impacts by the volcanic haze were also recorded; see Durand \& Grattan (1999) and references therein. Some con- 
temporary sources in Europe link the haze to illness and mortality (see Grattan et al. (2003) and references therein), although in some of these sources, the wording suggests contagious disease rather than pollution, e.g. 'A fever rages in many parts, which the people term the Black Fever' (Gilpin, England, cited in Grattan et al. (2003)). As outlines above, unusual summer mortality occurred in parts of England and France from August 1783. Grattan et al. (2003, 2005) point out that excess mortality over such a large area suggests a common, probably environmental driver. Clearly, the Laki haze would be such a driver, but so would excessive summer heat. Witham \& Oppenheimer (2004) also investigated the hypothesis that the high temperatures in July might have caused the observed mortality in England. They find that high July temperatures tended to be followed by an increase in mortality of around 5\%/degree warming in $\mathrm{Au}$ gust and September, probably through indirect effects such as fostering disease. However, in 1783 , the heat effect only explains $30 \%$ of the excess mortality in England, though extrapolation errors might occur. Witham \& Oppenheimer (2004); Grattan et al. (2003, 2005) all consider it puzzling that mortality only increased in August, while strong haze had been present from the end of June (Thordarson \& Self, 2003), and modern air pollution events (though they may be imperfect analogues to the Laki haze) affect mortality at shorter lags. For 625 comparison, Michaud et al. (2004) found that hospital emergency room visits for asthma and Chronic Obstructive Pulmonary Disease followed exposure to SO2 and fine sulphuric acid aerosol at Kilauea, Hawaii, at lags of only 1-3 days. An additional argument for caution in attributing European mortality solely to the Laki haze is the absence of clear evidence for a major pollution-induced mortality crisis in Iceland in summer 1783. Unless this lack is simply due to gaps in the record, it seems puzzling that France and England should have been more affected than Iceland, where concentrations were much higher.

Comparison with modern events might help to understand the effect of the Laki haze, but quantitative studies of the effect on long-term exposure to strong 635 volcanic pollution are rather scarce (Hansell \& Oppenheimer, 2004; SierraVargas et al., 2018). Two studies at Miyakejima volcano, Japan (Iwasawa et al. 
2009; Kochi et al. 2017) found that exposure to average concentrations of up to 45 ppb SO2 over 2 years (with 100ppb exceeded $5 \%$ of the time and 5 -min peaks exceeding $5 \mathrm{ppm}$ ) were not associated with reduced lung functions, although irritations such as increased cough, throat pain and painful eyes were wide-spread. B.M. et al. (2008) finds that in Hawaii, chronic exposure to SO2, with an average concentration of $49 \mathrm{ppb}$ (hourly range: $0-1,700 \mathrm{ppb}$ ), caused damage to crops and livestock, and increased blood pressure as well as respiratory and eye irritation in humans, but does not report severe illness or increased mortality. For comparison, in the modelling study of Balkanski et al. (2018), 48ppb were exceeded in Iceland on 55 days in June-September 1783, with a maximum daily mean of $114 \mathrm{ppb}$. If the model is correct, then SO2 exposure in Iceland was of similar magnitude as in the Hawaiian and Japanese studies, where no mortality crisis occurred. However, PM2.5 exposure was low in Hawaii and Japan and may have been higher during the Laki eruption.

Schmidt et al. (2011) performed a model simulation to estimate the excess mortality in Europe through PM2.5 in a present-day Laki-style eruption. They predicted 140,000 excess deaths. This is a lower mortality per population than was found for 1783 by Grattan et al. (2003, 2005), but the result can not be directly translated to the 1780 s, as it uses different background concentrations (present-day vs pre-industrial). Balkanski et al. (2018) modelled PM2.5 and SO2 concentrations in June-September 1783 over France, using reconstructed weather patterns from 1783, and found that these pollutants cannot account for the excess mortality observed in France that summer. For Iceland, they do find an increase in mortality risk (compared to an unexposed population) by $13-30 \%$ from SO2 and about $60 \%$ from PM2.5. It is difficult to discern a signal of this magnitude in the Icelandic mortality data for summer-autumn 1783, except maybe the increase in mortality between the first and second half of 1783 in north Iceland. However, the small sample size and generally the strong variability of 18th century mortality in Iceland prevent firm conclusions. Both Schmidt et al. (2011) and Balkanski et al. (2018) point out that major uncertainties arise from the assumed relation between concentrations and mortality. In particular, 
susceptibility in the 18 th century may differ from modern times, e.g. due to lower background exposure and lack of health care.

670 irritation resulting from the Laki haze, but it is less clear to what extent the haze contributed to excess mortality in Iceland and the rest of Europe. In my view, the hypothesis of a haze-induced mortality crisis should be treated with caution, since correlation is not causation and irritation symptoms not necessarily imply 675 death.

\section{Vulnerability: The fish and sheep paradox}

In summer 1784, foreign fishing vessels were observed to make good catches on the open sea off Norður- and Suður-Múlasýsla - out of reach for the small boats of most hungry farmers (see SM4). In the same year, the progressive treasurer Skúli Magnússon wrote about the Laki eruption: 'It looks as if Nature wanted to teach man to show more caution in the future and have better control over his breadwinning' (cited in Gunnarsson (1984)). Here it will be discussed how the socio-economic situation in Iceland (outlined in sect. 3.1 influenced vulnerability to famine (sect. 3.2 .

\subsection{Iceland's socio-economic situation}

\subsubsection{Absolutist government}

Iceland was a dependency of Denmark-Norway, and was ruled from Copenhagen. The administration was ordered in a very hierarchical fashion (see fig. 4), for Denmark-Norway was an absolutist monarchy. All power officially lay with the King by God's grace. King Christian VII, however, was mentally ill and unable to reign, and de facto the power lay with those who attained control over the king. From 1772, this had been the conservative Ove Høegh-Guldberg, but in April 1784 he was forced to resign after a coup d'état by the sixteen years old crown prince Frederick, who became prince-regent thereafter. Although 
making was left to lower administrative bodies, especially the Rent Chamber (Rentekammeret, the finance department), which issued orders to and received annual reports from the Icelandic officials.

There was no nobility in Iceland. The highest official on the island was the lute monarchy. In reality, Icelandic officials were often consulted by the central government (Karlsson, 2000, ch. 2.12). Still, Stephensen \& Sigurðsson (1854) shows that the Danish authorities minutely regulated even minor administrative issues such as the height of contributions to an insurance for widows of Icelandic 725 reverends or funding for repairing old medical instruments (a cost of 11 ríkisdalir 82.5 skildingar, roughly the value of two cows). The instructions for the 
The administration of Iceland, around 1783

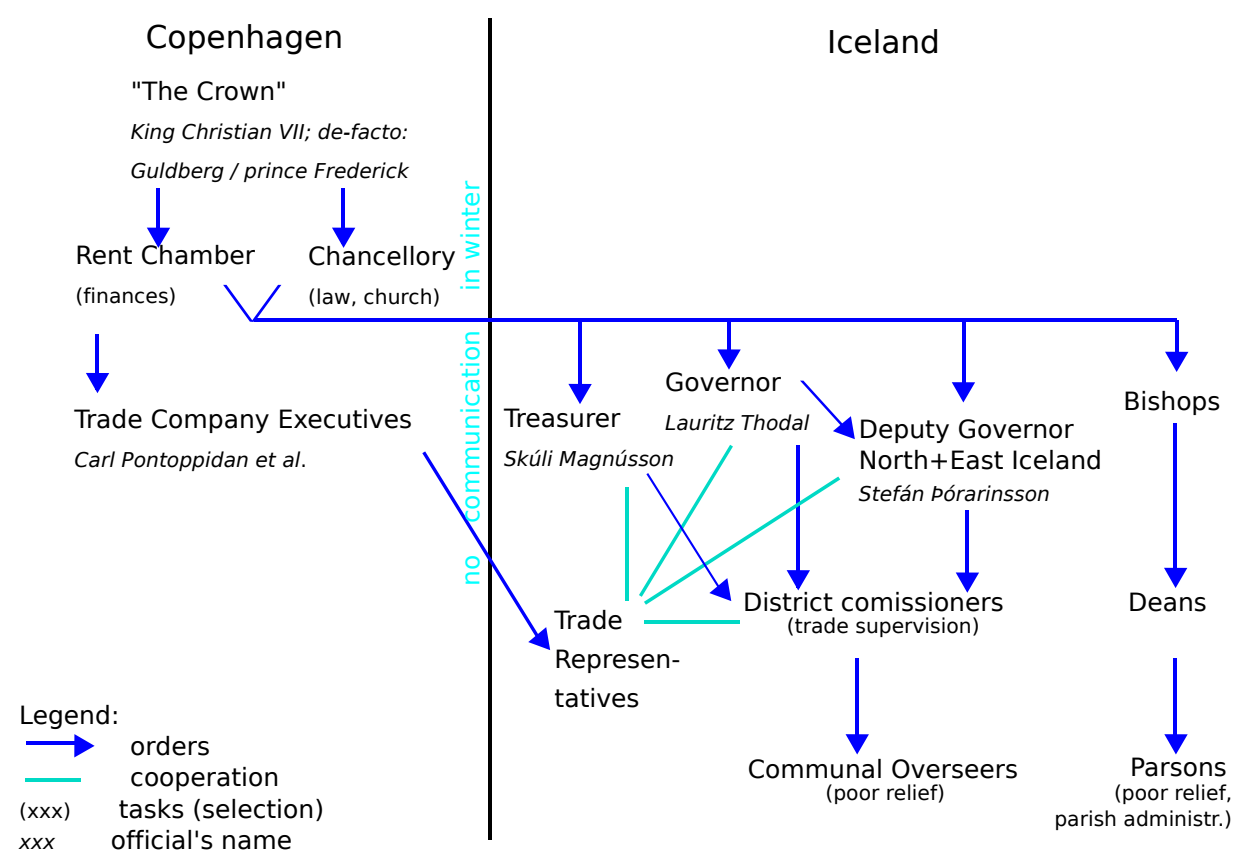

Figure 4: Structure of the administration of Iceland in the late 18th century. The names of the officials are for July 1783-April 1785. Based on (Gunnlaugsson, 1984b; Gunnarsson, 1983; Steingrímsson, 1791/2002, , p. $309 f f$ (comments by translator)).

newly appointed Stefán Pórarinsson (Stephensen \& Sigurðsson, 1854, vol. 4, p. 728-740) repeatedly order him to submit suggestions, complaints, or observations to the Rent Chamber. These examples suggest that, while the Danish authorities valued the opinions of Icelandic officials, it also wished to exercise close supervision. Stefán Pórarinsson's orders do not consider the need for independent action in possible emergencies. However, as crossing the North Atlantic in the stormy season was considered infeasible, no communication was possible between Iceland and Copenhagen during the winter, making it impossible for Icelandic officials to quickly consult their superiors in the capital. 


\subsubsection{Farming and Fishing}

The Icelandic economy consisted mainly of subsidence farming, combined with some fishing. There were no urban centres (the largest settlement, Reykjavík, had about 200 inhabitants), and people mostly lived in individual farms. 1854, vol. 4, p. 278).

Remarkably, although the sea around Iceland is rich in fish, relatively little use was made of it; fishing remained a sideline, secondary to farming. It has been estimated that about $2 / 3$ of the catch (amounting to $110 \mathrm{~g}$ of dried fish or coastal shipping hardly existed.

Farming was limited by the harsh climate; grain would not grow, vegetable patches were scarce, and farmers mainly kept cows and sheep for food (mostly dairy), clothes (wool) and light (tallow). Wild food could complement farming products: land-based sources included birds and eggs, lichens (cetraria islandica), berries, and freshwater fish, while the sea provided sea shells, seals, and of course fish Hambrecht (2009). Horse meat was usually not eaten Andrésson (1984), due to religious traditions going back to a papal decree of 732AD which condemned its consumption. Neither the reformation around 1550 nor the lifting of the legal ban on horse meat in 1757 put an end to this tradition. In the time between settlement and the Laki eruption, farming had rather become more difficult by slowly progressing soil erosion reduced agricultural land Friðriksson (1972); relatively (though not uniformly) cold climate since about 1200 Ogilvie \& Jónsson (2001). It has been argued that certain farming techniques that could have improved farm productivity, like building fences to protect hay land from animals or drainage of marshy land Gunnarsson (1980); Vasey (2009), had been abandoned, possibly partly because short-term tenancy discouraged farmers from improving their land Eggertsson (1998). In the second half of the 18th century, the Danish government tried to (re-)introduce these techniques, e.g. ordering farmers to build fences and level their land (Stephensen \& Sigurðsson,

roughly $400 \mathrm{kcal} /$ person/day) served for domestic consumption and the remain- 
der, mostly high-quality dried cod, was exported (Karlsson, 2000, ch. 2.14). Valuable migratory cod was abundant in the Southwest of Iceland in winter and spring, and in the Northwest in spring (i.e. in a time when there was little farm work). The cool and windy conditions were favourable for wind-drying fish. In the North and East, fishing was possible from spring (if not hindered by sea-ice) to autumn, but had to be interrupted from July to mid-autumn for hay making (Ogilvie \& Jónsdóttir, 2000). Farmers in these regions could send their farmhands to the southwest to either participate in the winter fisheries or barter fish for farming products.

Fishing was hampered by technological level (using open rowing boats, rather than decked vessels like foreign fishermen visiting Iceland), and by administrative measures; the formation of fishing villages was prevented by a law prescribing that everybody had to be registered at a farm - either as farmer (owner or tenant) or as farmhand (Gunnarsson, 1983; Eggertsson 1996) The cited studies suggest several interrelated reasons for the low intensity of fishing: That the Danish crown isolated Iceland from foreign merchants (potential eager customers) for fear of loosing control over the island; that artificially low fish prices (set by the Crown) lowered the incentive for fishing; that most Icelanders lacked the means to invest in more seaworthy vessels; that fishing was considered an insecure source of income, so that unlucky fishermen might overwhelm the poor relief system (sect. 3.2.3); and that the landowning elite and farmers opposed full-time fishing for fear to loose their cheap labourers. These factors kept Iceland in a "poverty trap" of relatively unproductive subsistence farming, underusing its richer resources. Contemporaries such as Skúli Magnússon and some directors of the Monopoly trade (sect. 3.1.3) considered fishing as vital for developing the Icelandic economy. In 1776, it was attempted to stimulate fishing by increasing the fish price and handing out premiums, but at least initially this measure did not entice the Icelanders to do more fishing (Gunnarsson, 1983, p.169). Whether these measures would have stimulated the economy in the longer run if the devastating Laki eruption had not occurred, remains speculation. 


\subsubsection{Monopoly Trade}

This section is based on the extensive study by Gunnarsson (1983).

Iceland was not a self-sufficient economy: It depended on the import of 


\subsection{Resilience to Famine}

Jónsson (2009) estimated that male and female farmhands were entitled to rations of 3300 and $2600 \mathrm{kcal} /$ day, respectively. Taking into account that children and possibly non-working elderly ate less, I will use $2500 \mathrm{kcal} /$ day as a rough estimate for normal average calorie intake. In normal years, Icelandic food production was adequate: During the census of 1703, Iceland had 24467 cows and 167937 ewes. A cow could produce about 1600 litre of milk per year (Jónsson, 2009). If the traditional value ratio " 1 cow $=6$ ewes" reflects milk production, then milk could have provided $2500 \mathrm{kcal} /$ day for 57000 persons (assuming $625 \mathrm{kcal} / 1$ milk). The actual population in 1703 was only 50358 (Karlsson, 2000, ch. 2.14) and had also access to other food than milk. Nonetheless, devastating famines as well as periods of local distress occurred (Finnsson, 1796). In the following, the Icelanders' possible 'lines of defence' against famine, from household to government level, are briefly discussed.

\subsubsection{Population pressure and population control}

Bishop Hannes Finnsson (Finnsson, 1796) argued that Iceland was clearly not uninhabitable, for there were enough good years to allow the population to recover from the bad ones. Yet, the population never grew much beyond 50000 in the 18th century, which has sometimes been interpreted as evidence for a maximum carrying capacity of the Icelandic soil. However, Vasey (1991) argues, based on mortality data for 1740-1799, that there was no extreme pressure on food reserves in ordinary years, because mortality did not peak in spring (when food would have been scarcest), except for 6 'bad' years, including 1784 and 1785. The population ceiling was a product of birth control rather than endemic hunger (Gunnarsson, 1983; Vasey, 2009): Acquiring a farm was required for marriage, and since the number of farms was roughly fixed, the number of married couples was limited. This led to high celibacy rates and late marriages. Once married, however, Icelandic women had very high fertility rates (Vasey, 2009). Requiring a farm as base for marriage thus prevented population growth to overstretch the food production of the farming community. On the other 
hand, the same convention helped to prevent the development of fishing villages and thus limited the access to marine resources (Gunnarsson, 1983; Eggertsson, 1996).

\subsubsection{Food production and storage}

The strong variability of the Icelandic climate has significant impact on grass growth and hay production. It has been estimated that a temperature anomaly of 1 degree $\mathrm{C}$ over October-April (i.e. a very severe winter) reduced grass growth by $30 \%$ (Bergthorsson, 1985). Both inadequate grass growth and rainy summer weather reduced the hay crop. Although most winters had mild intervals in which the animals could graze, the hay harvest was of utmost importance to keep the livestock alive. In autumn, after the hay harvest, farmers had to decide how many animals they would try to keep alive over the winter; the rest was slaughtered. If the winter was colder or longer than expected, then a considerable part of the livestock could be lost. Storing extra hay was a potential means to protect livestock against bad weather (or eruptions). However, farmers tended to take considerable risks, often not reducing their herds sufficiently in autumn to get their animals through a harsh winter (Eggertsson, 1998), which could lead to large losses of sheep even under conditions far less extreme than the Laki eruption. In 1784, farmers in several regions regretted not to have reduced the livestock sufficiently in the previous autumn (see SM3), though there exists an example of two unusually provident brothers in Isafjarðarsýsla, who kept a large hay stock and were forced by the district commissioner to sell hay to their neighbours, saving the life of 50 cows.

Food storage or alternative food sources could be used to buffer against loss of livestock. Icelandic farming was centred around preserving food. Steingrímsson (1788/1998) reports that several (wealthy) farmers had more than enough food to last through the crisis of 1783-85; probably even poorer households accumulated some reserve in good years. Several bad years were usually needed cause famine (Finnsson, 1796), so Icelandic households (like in most societies, (Ó Gráda 2009)) must have had reserves to cope with single harsh 
years. Icelandic farmers could also fall back on food sources not normally used, for example sea shells Hambrecht (2009), the meat of diseased or culled dairy animals (which fed the people in Eyjafjarðarsýsla at least till December 1783, 


\subsubsection{Distribution and social safety net}

At least in principle, everybody in Iceland was entitled to food and shelter (Eggertsson, 1998). Servants were mostly paid in food, shelter and clothes, and working contracts between farmers and farmhands started in the beginning of June (i.e. the busy farming season) and lasted for a year; servants could thus not be turned out in winter or in case of temporary illness. Households with sufficient means were obliged to take in their poor relatives, and poor people without suitable relatives had to provided for by their commune (hreppur). The communes could also support households that were in temporary difficulties.

Food was thus fairly well distributed among farmers, workers, and paupers on communal assistance, although vagrants and beggars also existed. However, this safety net operated only on a local level (there were about 160 communes in Iceland), hence climate or volcanic risks could affect the whole commune and overwhelm the system. After the Laki eruption, several communes had more than two paupers per household, partly because farmers could not afford to hire farmhands, who then became paupers (Finnsson, 1796). In many regions, farmers were forced to give up their farms and become vagrants (see also SM8).

There was no strong relief organisation beyond the local level, except some church charity. The bishops of Skálholt donated 20 ríkisdalir from a 'fund for the poor' to the parishes closest to the Lakagígar (Steingrímsson, 1791/2002, ch. 41) - the value of 20 ewes for a population of several hundred persons. Neither the communes, nor another authority, organised food stores; this would likely have been difficult because building and transport were expensive. The Land 40 Commission of 1770 suggested to build emergency stores at all trading centres to prevent famine. This suggestion was not carried out (Andrésson, 1984); instead, an emergency credit system was decided upon, see sect. 3.2.4.

\subsubsection{Trade}

Trade can smoothen local food shortages. Domestic trade within Iceland was common, e.g. farming against fishing products. However, under severe distress, it could happen that farmers (or fishermen) had nothing to barter. Transport 
was also a limiting factor, because overland transport relied on horses (and healthy men), which often lacked during farming crises (see SM7\&8). Coastal shipping or navigable rivers hardly existed.

The monopoly trade company both imported and exported food. Grain import averaged 16950 Danish tons or $1.4 \times 10^{6} \mathrm{~kg}$ over $1763-84$ (Andrésson, 1984), whereas the export of mutton amounted to 3223 barrels $\left(4 \times 10^{5} \mathrm{~kg}\right)$ around 1770 and dried fish to 8120 skippund $\left(1.3 \times 10^{6} \mathrm{~kg}\right)$ (Gunnarsson, 1983). As a rough estimate, assuming a population of 50000 and a daily calorie intake of $2500 \mathrm{kcal} /$ person, imports and exports amounted to 41 and 47 daily rations, respectively. The export volume can be regarded as the maximum buffer provided by trade: Under the extreme assumption of a distressed population obtaining the imported grain without handing in any of the food products earmarked for export, about 7 weeks of additional food could have been gained with respect to normal years. This would require either the possession of sufficient non-food tradable goods, or cash reserves, or a credit system. Many households lacked tradable goods in bad years. Woollen products were the most important nonfood export good, but wool could be scarce when very many sheep were dying, at least in the second winter, after the wool from dead sheep was used up. Cash reserves were scarce; in fact, farmers used to be indebted with the merchants, obtaining goods for credit in early summer and paying with farming products by the end of the year (Gunnarsson, 1983).

The trade regulations from 1776 stipulated that if widespread hunger threatened, the governor, deputy governor and district commissioners could ban the export of Icelandic foodstuff (Andrésson, 1984). In addition, the merchants were obliged, in cooperation with the district commissioners and communal overseers, to give farmers in distress an emergency loan of foodstuff and tools, typically for one year. This rule was clearly meant as a temporary relief measure and did apply neither to officials, who were considered wealthy enough to not need emer975 gency loans, nor to persons considered unlikely to be able to pay back the loan. However, it is doubtful whether this law could have prevented a nation-wide famine, because the trade company did not have significant emergency stores 
of food in Iceland, particularly in winter. To make things worse, in early 1783 , the authorities in Copenhagen felt that the emergency loans had been abused fying the economy, increased trade volume per person, allowed households to 
build up cash reserves to access food import during shortages, and facilitated domestic trade by providing boats for coastal transportation. In a pessimistic scenario, the fishing sector could have lead to unsustainable population growth by removing the birth control mechanism, disrupted the communal insurance system, and created a class of poor fishing labourers working for low wages without fixed contracts, who might have been at greater risk of hunger than farmhands in the actual subsistence farming society.

\section{Capability: Disaster (mis)management}

Iceland clearly had insufficient resources to cope with a loss of about half of its cows and $3 / 4$ of its sheep, and the modest means at hand were ill used (see below). Therefore help would have to come from outside - from Denmark. Yet communication between the two countries was difficult, and the Danish authorities, although in principle willing to help, only sent significant relief about 13 months after the eruption.

\subsection{Troubled communication}

\subsubsection{Reports to Copenhagen in 1783}

In the vicinity of the Lakagígar, sheep and cows died massively within weeks and thus the threat of a (local) famine quickly became imminent. Reverend Jón Steingrímsson of Kirkjubæjarklaustur, as the dean of Vestur- and AusturSkaftafellssýsla, reacted quickly and wrote several reports to the bishop in Skálholt, asking for financial aid for himself and other local parsons Rafnsson, 1984b). On July 4th, he also sent a letter to deputy governor Ólafur Stephensen (who was replaced in mid-July 1783 by Stefán Pórarinsson), which ends with a cautiously worded plea for government help: "May God have mercy upon us $[\ldots]$ and awaken the hearts of the officials so that they report the misery which befell this district to His Royal Majesty, who in His mercy will not let us die from hunger and wretchedness" (Steingrímsson, 1783). Ólafur Stephenson passed this letter on to Copenhagen along with his own report dated August 


\begin{tabular}{|c|c|}
\hline time & event \\
\hline 1783, June 8th & Onset eruption \\
\hline 1783, July & Letters of rev. Jón Steingrímsson to bishop \& deputy governor \\
\hline 1783, end of August & News of eruption reaches Copenhagen (letter from merchant) \\
\hline 1783 , Oct. 11 th & Investigation ship departs towards Iceland (but hibernates in Norway) \\
\hline 1784, winter-spring & Severe famine in Iceland, worst in the north \\
\hline 1784, January & Money collection in Copenhagen to aid Iceland \\
\hline 1784, February & Eruption ends \\
\hline 1784, April 14th & De-facto regent Guldberg disposed by crown prince Frederick \\
\hline 1784, April 16th & Investigation ship arrives in Iceland \\
\hline 1784, May 14th & Deputy governor asks Danes for fish transport to north \& econ. support \\
\hline 1784, July & Emissaries investigate Vestur-Skaftafellssýsla \\
\hline 1784, mid July & Full news of famine reaches Denmark; ca $440,000 \mathrm{~kg}$ grain sent to Iceland \\
\hline 1784, Aug. 14th & Devastating earthquake in SW Iceland, destroying 400 farm houses \\
\hline 1784, Aug. 26th & Danish ship with orders concerning fish aid sinks off South-Iceland \\
\hline 1784 , late summer & 1.2 million $\mathrm{kg}$ dried fish ( $\approx$ usual amount) exported from Iceland \\
\hline 1784 , autumn onward & infectious disease ('landfarsótt') especially in western Iceland \\
\hline 1785, winter-spring & second hunger winter in Iceland \\
\hline 1785, February & Copenhagen: Commission founded; second money collection decided \\
\hline 1785, June 22 & several aid measures decided upon (though with limited success) \\
\hline 1785, summer & improving weather; famine ends \\
\hline 1785, Nov. - 1787, Mar. & small pox epidemic (unrelated to eruption?) \\
\hline
\end{tabular}

Table 3: Timeline of the eruption and measures taken. 
15th (Stephensen, 1783). The governor, Lauritz Thodal, only informed the government on September 16th (Gunnlaugsson \& Rafnsson, 1984, comment by editors in section II), because he first wanted to gather more precise information - a serious delay seeing that autumn was approaching and thus the time window for shipping over the North Atlantic was closing. The first news of the eruption received in Copenhagen were not an official report but a few, rather inaccurate remarks in a letter by merchant J.C. Sünckenberg of Reykjavík to the directors of the trade company. His letter, dated July 24th, mentioned the destruction of two churches and eight farms by lava, thick sulphuric haze, bad grass growth and illnesses in grazing animals. It reached the capital at the end of August.

\subsubsection{The investigation ship and Danish hibernation}

Despite the vagueness of the first reports, the Rent Chamber took action and decided on September 17th to send a ship to Iceland to investigate the situation (Gunnlaugsson, 1984b). The ship was loaded with some grain, and aboard were two emissaries, the young lord-in-waiting and Rent Chamber member Hans C.D.V. von Levetzow "who likely desired soon to take the place of the current governor of Iceland" (Stephensen, 1888, p.229) and the student of law and natural science Magnús Stephensen, a son of the former deputy governor Ólafur Stephensen. They were ordered to investigate how best to help the victims, including fugitives, and which of the damaged farms could be made inhabitable again. In addition, Magnús Stephensen was told to investigate the eruption scientifically, including taking samples with an earth drill (Stephensen, 1785, p.XIV) to search for traces of lignite (to test the contemporary theory that volcanic eruptions were caused by subterranean coal fires). They were also ordered to search and investigate a new island which had formed in spring 1783 off Reykjanes during a submarine eruption. The Danish authorities were anxious to take formal possession of this island to forestall other nations to use it as a base for fishing in Icelandic waters or even break the trade monopoly (Stephensen \& Sigurðsson, 1854, vol. 4, p.744ff). They needn't have worried: The island was eroded before anyone found it again (Stephensen, 1888, p.252). 
The ship departed another three and a half weeks after the Rent Chamber session, on October 11th. Around that time, further worrying news arrived from Iceland, including Thodal's report and Jón Steingrímsson's letter. The Danish authorities were now convinced that something serious was happening in southern Iceland (but had no idea that the north might also be affected). On October 23rd, the Crown issued an order (Stephensen \& Sigurðsson, 1854, vol. 4, p. 763-764) that needy persons in southern Iceland should obtain food from the trading posts without payment, under supervision of governor Thodal. However, this order came too late to be shipped to Iceland before winter, because the investigation ship had already left. The decree of October 23rd also approved a suggestion by Carl Pontoppidan, the executive of the royal Iceland trade, to collect money in Copenhagen to support the Icelanders. The collection was eventually held in January 1784 and yielded almost 10000 ríkisdalir (Gunnlaugsson, 1984b).

Meanwhile, the investigation ship had run into several Atlantic autumn storms. After three attempts to reach Iceland, it took winter shelter near Kristianssand in southern Norway (Stephensen, 1888, p.236-237). Due to the advanced season, no further attempts were made to reach Iceland. The investigation ship departed again for Iceland in early March, carrying part of the collected money (1700 ríkisdalir) for distribution to the farmers from the devastated area. Due to further inclement weather, the ship only arrived there on April 16th 1784.

\subsection{Food aid and food trade}

\subsubsection{Loans and export bans (1783)}

1090 Already in his letters to Thodal (Guðmundsson, 1783a, July 26th)) and the Rent Chamber in Copenhagen (Guðmundsson, 1783b, August 2nd)), district commissioner Lýður Guðmundsson complained that the stricken inhabitants ofVestur-Skaftafellssýsla were denied the customary emergency loans at the trade post and asked his superiors to persuade the merchant to hand out foodstuff for the needy. He did not mention any intention to try persuading the 
merchant by himself, even though district commissioners were co-responsible for overseeing the trade. It might have played a role in Lýður Guðmundsson's case that the nearest trading post, Eyrarbakki, was outside his district, in a region less affected by the eruption, making it harder to persuade the merchant of the gravity of the situation. However, many other district commissioners were also unsuccessful in forcing the merchants to give emergency loans (see SM7). This was probably partly due to the recent orders regarding outstanding Icelandic debts (see section 3.2.4). Many Icelandic officials, trying to argue that these orders did not apply in case of actual famine, had a weak position because they themselves were indebted to the trade company and thus at the merchants' mercy, and the merchants were reluctant to disregard the recent letters without consent from Copenhagen (Andrésson, 1984). This consent, of course, could not be obtained with winter approaching.

Similar difficulties arose concerning the ban of exporting Icelandic foodstuff (Andrésson, 1984). The merchants had direct financial interests to export as much as possible from Iceland, because merchants received $1.5 \%$ of the value of their exports as top-up on wages and merchants' assistants $0.5 \%$. In late summer 1783, the Icelandic governor and district commissioners did not enforce an export ban. Of course, the crisis had not fully unfolded by then, but the with$\mathbf{1 1 1 5}$ ering of the vegetation and reduced milk production had manifested themselves in many trade districts. As a result of the exports, no significant emergency stores were at hand in Iceland in autumn 1783.

In the course of the winter and spring 1784, the fishing season in southwestern and west Iceland was not bad, and the merchants succeeded in acquiring the usual amount of fish from Icelandic fishing boats: around 1.5 million $\mathrm{kg}$ (Andrésson, 1984). In addition, the trade company caught fish with its own vessels. In spring 1784, Thodal banned the export of butter and tallow, but not fish (probably the most desired export good). Stefán Pórarinsson banned the export of all Icelandic foodstuff from his harbours until further notice; the merchants were obliged to sell such goods back to the population for the purchase price (see SM7). But northern and eastern Iceland had only very limited 
fishing and, due to the livestock decimation, also very limited meat products, hence this export ban was little effective.

On the district level, while district commissioners complain about the unwillthe trade company employed for fishing - straight back to Copenhagen with the bad news.

In northern Iceland, the sea ice blocked the coast until the end of May (SM1,Guðjónsson (2010)), preventing all communication by sea. On May 14th, 1155 deputy governor Stefán Pórarinsson wrote a lengthy report [in Rep1784; see also SM] to the Rent Chamber and sent it over land to Reykjavík, hoping that 
shipping would be possible from there. In his report, he submitted numerous suggestions on how to aid the impoverished and starving population. The most notable short-term measures suggested sending 8000 Danish tons 5 (ca $667,000 \mathrm{~kg}$ ) of grain to North Iceland, and also a shipload of (low-quality) dried fish from the Icelandic fishing regions to the north. Part of the aid measures might be financed by a special tax on luxury goods such as brandy, tobacco, and coffee. In the longer run, the deputy governor suggested the donation of whaling ships, and stimulating employment for those who normally processed wool (which was now impossible due to the loss of sheep), e.g. by regulations against exporting unprocessed eiderdown, which should be processed within the country.

Stefán Pórarinsson's letter reached Copenhagen with the returning investigation ship in July 1784. Thodal's reports (in Rep1784) do not indicate that he was familiar with the content. Either Stefán Pórarinsson did not inform Thodal or Thodal ignored his letter; but certainly Thodal did neither send Icelandic fish to the northern harbours nor decree a full ban on exporting Icelandic foodstuff (Andrésson, 1984).

\subsubsection{Flour and fish (summer 1784)}

In spring 1784 , the ordinary trading ships were sent to Iceland earlier than usual and given strict orders to do everything possible to reach their destination (Andrésson, 1984). Should a harbour be blocked by sea ice, the ship should not return to Denmark but wait in the vicinity for the ice to break. However, no significant additional amount of foodstuff was shipped to Iceland this spring: Compared to the 1764-1784 mean of 16950 tons, 24203 tons of grain were imported in 1784, i.e. 7073 tons above average; but of these, 5300 tons were only shipped after mid-July.

On April 19th, the Crown issued a decree (Gunnlaugsson, 1984b; Stephensen

\footnotetext{
${ }^{5}$ a grain ton was a volumetric measure, equal to 139 litres. It was specified that 1 ton of grain should weigh at least $83.4 \mathrm{~kg}$ (Gunnarsson, 1983, p. 41).
} 
\& Sigurðsson, 1854, vol. 5, p. 45-46) that Thodal and Levetzow, together with Stephensen \& Sigurðsson, 1854, vol. 5, p.99-100); by autumn, 5300 tons had been sent (Stephensen \& Sigurðsson, 1854, vol. 5, p.106-107). In addition, a letter dated July 17th was sent to Eyrarbakki, decreeing that part of the fish catch from West Iceland (which was of lower quality than the fish of Southwest Ice- 
1215

1220

land) should be transported by the vessels of the trade company to the harbours where the need for food was greatest, i.e. northern and eastern Iceland. Unfortunately, only one of the ships sent to Iceland carried instructions concerning the fish, and this ship was shipwrecked off the coast of Vestur-Skaftafellssýsla, and the letters got lost (Andrésson, 1984). Governor Thodal and the district commissioners in the fishing regions still did not dare to declare a ban on exporting foodstuff without explicit orders from Denmark. Thus in late summer of 1784, the merchants exported nearly all fish they had acquired during the last spring, namely 7558 skippund $(=1,200,000 \mathrm{~kg})$ bought from Icelanders plus their own catches. No fish transports took place towards the north and east (Andrésson, 1984). In the following winter, another several thousand Icelanders died, for a large part of starvation (or landfarsótt). 1,200,000kg of fish could have provided $2500 \mathrm{kcal} /$ day to 50000 persons for about 5 weeks. Meanwhile, the Danish merchants profited considerably less from the fish than expected: Fish prices, which had been unusually high during the American war of Independence, had dropped dramatically after the Treaty of Paris in summer 1783, from 0.17 ríkisdalir/kg (averaged over 1780-82) to 0.12 ríkisdalir/kg (1783-87) (Gunnarsson, 1983, p. 151).

Even the food aid which did reach Iceland was not necessarily effective, especially in the remote areas, due to the lack of horses required to transport food from the harbours overland (Andrésson (1984) SM7). An attempt to ship some grain from the Vestmannaeyjar trading post to Dyrhólaey (see fig. 2) in the particularly remote Vestur-Skaftafellssýsla district was given up due to bad weather. Reverend Jón Steingrímsson complained that it would have been more effective to provide his parishioners with fishing and sealing gear, which would have allowed them to feed themselves to some extent (Steingrímsson, 1791/2002, p. 84-85). 


\subsection{The second year: Good intentions with meagre results}

\subsubsection{Total evacuation? (Autumn 1784)}

After the bad news of the famine in winter 1783/84, further bad tidings

1245 ties now considered Iceland uninhabitable and contemplated a complete evacuation by relocating the remaining Icelandic population to Jutland in Denmark. However, written protocols do not support this hypothesis, although it remains possible that a complete or at least large relocation has been considered orally moving 500-800 unproductive persons (the elderly and infirm, beggars and orphans) to Denmark. Apparently, this proposal lead to heated discussions in the Rent Chamber in early 1785. Levetzow suggested using the military in case the evacuees proved unwilling, while the high Rent Chamber official Jón Eiríkson (a native Icelander) considered the use of military forces against a peaceful population as a breech of law and pointed out that Iceland had no resources to feed hungry soldiers (Eiriksson 1984). The whole plan was given up shortly afterwards.

\subsubsection{Donations and Debts (1785 and beyond)}

In February 1785, a special commission (named 'the later land commission', landsnefndin síðari) was set up to investigate how to restore the Icelandic economy (Gunnlaugsson, 1984b; Stephensen \& Sigurðsson, 1854, vol. 5, p. 118-120; 124-127). Among its members were Jón Eiríksson of the Rent Chamber, the executive board or the trade company, and Levetzow, who by then was appointed to replace the retiring Thodal as governor in April. 
The commission decided to put an end to the aforementioned evacuation plans (Stephensen \& Sigurðsson, 1854, vol. 5, p. $216 \mathrm{ff}$ ), and to hold a second collection of money, this time in all market towns of Denmark-Norway (Stephensen \& Sigurðsson, 1854, vol. 5, p.123-124). This took several months 1275 to organise, but eventually, about 36000 ríkisdalir were collected in 1785 (Gunnarsson, 1983, p.145). Some further aid measures were decided upon and confirmed by royal decree on June 22nd, 1785 (Gunnlaugsson, 1984b; Stephensen \& Sigurðsson, 1854, vol. 5, p. 216 ff): Iceland was to be provided with food stores for the winter, and 4 shiploads of fish were to be sent to northern and eastern Iceland and sold to the local population for the purchase price, i.e. without charging freight costs. Farmers in need were to be provided with emergency loans from the trade, but only under careful supervision by the district commissioners. In addition, the trade company should put two ships at the new governor's disposal in case it would prove necessary to ship further goods among Icelandic harbours. Norwegian timber was to be sent to the harbour of Eyrarbakki and handed out to the victims of the earthquake who needed to rebuilt their homes (Stephensen \& Sigurðsson, 1854, vol. 5, p. 121-123 ff). Timber and further material for building boats were also to be sent to the fishing districts of Gullbringusýsla and Snæfellssýsla, such that the fugitives from the North and Southeast could settle down as fishermen. Governor Levetzow had to supervise the handing out of the timber. Finally, the Rent Chamber sent orders that spring to the district commissioners to count the population and the remaining livestock. In particular, it should be investigated which farms were in urgent need of additional livestock to remain inhabitable; it was planned to provide these farms with money (from the collection funds) to acquire animals.

Not all of these measured proved as effective as was hoped. The Danes sent almost twice as much grain as usual (32200 rather than 16950 Danish tons), and three (not four) shiploads of fish were sent to the northern and eastern harbours, but no other shipments in between harbours were made (Andrésson, 1984), and there were repeated complaints by the Icelanders that it was difficult to obtain goods at the trade posts, partly because they were badly stocked (Gunnlaugsson, 
1984b). Note also that the food aid was not a gift; it was sold (albeit without profit) or handed out as emergency loan to eligible people, i.e. farmers in acute distress who were however expected to pay their debts.

Concerning the timber, it appears that Levetzow was very hesitant to hand it out (even though it was already paid for by the collection money), setting up a complicated bureaucracy for the applicants to prove their need (Andrésson, 1984). At the end, a good part of the timber, both in Eyrarbakki and the fishing districts, was never handed out but remained in the merchants' store and was sold in the course of time as ordinary merchandise. About the boat timber, Levetzow claimed that no new boats were needed because enough people had died the last two years to free up boat places for the fugitives, though it may be that he acted to please incumbent boat owners, who feared that new boats would make it more difficult for them to find labourers for their own vessels 1315 (Andrésson, 1984).

In some cases, fugitives were also sent back. For example, 40 paupers who had fled westward from eastern Vestur-Skaftafellssýla, were forced by Levetzow to return to their homes in early autumn 1785. By law, paupers were entitled to poor relief in their home commune. However, the 90 remaining, impoverished inhabitants had no means to provide for the 40 returning fugitives, and even the charitable parson Jón Steingrímsson wrote that nothing could be done but 'simply finding them a place to die' (Steingrímsson, 1788/1998, p. 88). At the end, the parish was saved by an exceptional catch of seals, but the episode clearly illustrates how rigidly authorities applied the law, and that aid was far from sufficient.

Nonetheless, the acute famine ended in summer 1785 (Hálfdanarson, 1984), probably because the weather and the hay harvest were very good that summer (Guðjónsson, 2010). However, many farms still suffered severe difficulties due to lack of livestock (Steingrímsson, 1788/1998, p.87). Already in April 1786 the

1330 Crown - under the impression of the past favourable weather and recent losses in the monopoly trade, inflicted by the eruption as well as low fish prices and high grain prices - ordered that fewer credits should be given in Iceland and debts be 
reduced as soon as possible (Stephensen \& Sigurðsson, 1854, vol. 5, p. 253-255). These orders were given despite the significant amount of money gathered in the collection in 1785 . The collected money remained largely unused and was saved as the so-called 'collection funds' in case Iceland should ever be hit by hardships again. The funds depreciated due to inflation and was eventually used in the 1840ies to construct a high school building in Reykjavík (Gunnarsson, 1983, p.145-146).

The attempt to aid farmers in urgent need for animals to replenish their livestock was not very successful: Not only was gathering the information a slow process, but what was worse, animals were scarce in the whole country, and it was nearly impossible to buy them (Gunnlaugsson, 1984b). A Danish request to England in February 1785 to export some English sheep to Iceland had been

1345 refused as the English were keen to protect their wool export Agnarsdóttir. 1992), and the Danes did not pursue the matter (Stephensen \& Sigurðsson, 1854, vol. 5, p. $216 \mathrm{ff}$ ). Still, some money (from the collection funds) was handed out to farmers in the following years and may have been of some help, although, as Jón Steingrímsson remarked, 'A great number of farmers and farms could have been restored more quickly if the money, which was given to them for the purchase of livestock, had not been taken back for the payment of rents and other debts' (Steingrímsson, 1788/1998, p.89). The considerable amount of unpaid Icelandic debts with the trade company 1783-88 may have been due not to leniency, but to the fact that many debtors had died of hunger (Gunnarsson, $13551984)$.

\section{Recovery and lasting effects of the Haze Hardships}

In his treatise on famines in Iceland, Finnsson (1796) wrote that 'Iceland never has been defeated by bad years to that extent, that during better years it could not recover, and feed its children'. This also holds for the Laki famine. Livestock was nearly restored after 12 years (see table 1 ). The population began to increase again after the smallpox epidemic of $1785-87$; more people were born 
than died each single year from 1787 to 1801, and in the decade 1791-1801 the population increase was 1-2\% each year (Gunnarsson, 1983, fig. 2.1). This rapid increase was facilitated by the high fertility of married Icelandic women (Vasey, 2009), and by the requirement of farm possession for marriage, which created a 'reserve' of unmarried labourers who could take over the deserted farms and found a family. In the region near Kirkjubæjarklaustur, 43 out of 47 destroyed farms and 9 out of 14 deserted crofts were eventually rebuilt, in some cases after re-location.

The events of 1783-85 made a small contribution towards urbanisation in Iceland: As the southern bishop's see in Skálholt had been largely destroyed by the earthquake of 1784, the later land commission decided to relocate it to Iceland's largest settlement, Reykjavík, then a village of about 200 people, which became the administrative centre of Iceland in the following years.

Although the old treasurer Skúli Magnússon remarked in 1784 that 'it looks as if nature is teaching the people to show in the future increased carefulness and to have better control over the economy' (cited in (Gunnarsson, 1980)), there was no 'building back better' of the economic system. The farming crisis could have lead to an abandonment of the most precarious farms and the establishment of fishing villages, maybe as a continuation of the (relatively ineffective) attempt in 1785 to provide fugitives the means to settle in southwest Iceland as fishermen (see sect. 4.3.2. However, neither was the vicious circle between poverty and the lack of seaworthy boats broken, nor were the laws changed which forced each individual to be registered at a farm (and helped to prevent the formation of permanent fishing villages). Thus, for the next decades, Iceland remained a subsidence farming community. The most significant economic reform caused at least partly by the Haze Hardships was the abolition of the monopoly trade in 1787/88 (Stephensen \& Sigurðsson, 1854, p. 416 ff). This measure was taken not so much to improve the freedom of the Icelandic population, but rather served to save government money: The Haze Hardships and unfavourable price changes abroad had rendered the previous trade company bankrupt (Gunnarsson, 1983, p.148-149). After 1788, the Iceland trade was 
free for all subjects of the Danish Crown, including the Icelanders themselves. Direct trade between Iceland and foreigners remained forbidden, as the Danes feared that such trade would eventually result in the loss of their sovereignty over the island. On the one hand, this new trade regulation allowed Icelanders to become involved in the trade. On the other hand, during the French Revolutionary Wars, new difficulties arose: Now the merchants were no longer obliged to visit Iceland annually (as had been the case during the monopoly period), they found it more profitable to use their neutral status to trade between $\mathrm{Eu}-$ ropean belligerents, rather than undertake the perilous journey to the remote Iceland, so severe shortages loomed there. An Icelandic appeal in 1795 to the Danish authorities to open the Iceland trade to foreign nations was not granted (Agnarsdóttir, 2013, p.27).

The Danish request in 1785 to import English sheep to Iceland had a rather bizarre aftermath, namely repeated attempts by British individuals, most notably Sir Joseph Banks of the Royal Society, to bring about a British annexation of Iceland to free the island from the 'Egyptian bondage' of Danish rule Agnarsdóttir (1992). These events culminated in the farcical 'Icelandic Revolution' of 1809, which did nothing to end Danish dominion, but helped to trigger the British government to magnanimously ensure the provision of Iceland with vital imports, as long as the sea blockade of the Napoleonic wars impeded the Danes from doing so.

In summary, although the Haze Hardships were perceived as a dramatic event and had inflicted much suffering in Iceland, they did not bring a turning point in history.

\section{Discussion: Was 'something rotten in the state of Denmark'?}

After the previous, mostly descriptive sections, one may discuss in which respects the reactions to the Laki disaster were adequate, or not - and whether any lessons can be drawn from the events. This question will be treated first by briefly examine pre-famine attempts to develop Icelandic economy, which 
determined the vulnerability to famine (sect. 6.1). Next, the magnitude of the disaster aid expenditure (sect. 6.2 will be discussed, and finally, the way in which these resources were put to use (sect. 6.3).

\subsection{Development aid without structural change}

Were the Danes to blame for Icelandic poverty and the catastrophic impact of climatic and volcanic events in the 18th century, as the 19th century nationalists claimed (Gunnarsson, 1984; Oslund, 2011, ch. 1)? Surely, Icelandic autonomy had declined in preceding centuries: With the reformation around 1550, the

1430 Catholic church had been abolished as authority on the island and much church land passed to the Crown; absolutism was introduced in 1662, and in 1602 the king established the monopoly trade (Gunnarsson, 1983, p. 53) to ensure that only his own subjects would enjoy the benefits of trade with Iceland. Iceland was expected to yield revenue to the Crown. For example, in 1684 the king, short of money after a war with Sweden, thoughtlessly changed the trade price list to the disfavour of the Icelanders, such as to be able to extract higher harbour rents from the merchants; his successor had to revert the change in 1703 after several years of famine in Iceland (Gunnarsson, 1983, p. 55-56). On the other hand, Iceland was maybe not treated worse than the Danish peasantry, let alone Danish colonies. As opposed to the Danish peasants, Icelanders did not live under serfdom (stavnsbåndet) and were not required to serve in the military.

With the age of Enlightenment, Danish treatment of Iceland changed. There were now active attempts to modernise the Icelandic economy. In the 1750ies,

1445 the treasurer Skúli Magnússon had persuaded the king to provide capital to develop manufactures in Reykjavík, mostly processing wool; the project failed due to, amongst other things, lack of inner-Icelandic markets for its products (farmers weaved their own cloth) and quarrels with the monopoly traders who refused to export the manufactured goods. In the following decades, the Danish government and Icelandic officials made some efforts promote development Oslund (2004), although these mostly aimed at incremental improvement within the 
subsistence farming system rather than structural change. Attempts to stimulate fishing were almost bound to be unsuccessful due to the laws restricting free labour; inconsistently, these laws were sharpened rather than abolished in early 1783 under the pressure of the landowning elite Gunnarsson (1983). Maybe the optimistic officials underestimated the difficulties of 'developing' a backward economy from behind a clerk's desk, with insufficient understanding of the societal fabric. The modern aim of (economic) 'progress' was only beginning to emerge in Europe (Ferguson, 2018, chapter 2) and was slower still to penetrate Iceland's rural, pietist community. Danish policy since the reformation had contributed towards reducing Icelandic autonomy and sustaining the poverty trap of rural subsidence, and the benevolent, but inconsistent 'development aid' bestowed by optimistic enlightened rulers in the second half of the 18th century failed to bring about a structural change and improve prosperity and hence (possubly) resilience to famine.

\subsection{Greedy or generous? The magnitude of Danish aid}

Over the years 1783-87, the Danish Crown supported the trade company with 76209 ríkisdalir to finance emergency grain import to Iceland (and, to a much lesser extent, the Faroe Islands). In addition, the trade company incurred losses of about 460000 ríkisdalir with the Iceland trade in 1784-1788, which hit both the Crown (ca. 260000 ríkisdalir) and private shareholders (Gunnarsson, 1983, p.142,144). It has been argued that these losses can partly be seen as indirect aid (e.g. unpaid Icelandic debts), while a substantial part of these losses was also caused by changing market prices outside Iceland and liquidation of the company 1787-88 (Gunnarsson, 1983, p.146 ff). The money raised during the collections in 1784 and 1785 was about 46000 ríkisdalir in total, but much of it remained unspent.

To assess whether this amount was 'large' or 'small', consider a few comparisons. In the traditional Icelandic price system, one ewe with a lamb cost 1

1480 ríkisdalur and one good milking cow 6-7 ríkisdalir. In summer 1784, ca. 31000 ríkisdalir were spent to purchase and transport to Iceland 5300 Danish tons of 
flour (Stephensen \& Sigurðsson, 1854, vol. 5, p. 215-216), enough to provide 40000 people with $2500 \mathrm{kcal} /$ day for ca. 16 days (assuming $83.4 \mathrm{~kg} /$ Danish ton and $3460 \mathrm{kcal} / \mathrm{kg}$ flour). As this grain was not necessarily handed out for free in Iceland, the actual costs may have been lower than the initial costs of 31000 ríkisdalir. The 1.2 million $\mathrm{kg}$ of fish which were exported in summer 1784 would have cost 54000 ríkisdalir in Iceland (abroad, prices were considerably higher). These comparisons show that the government expenditure after the Laki eruption was a significant amount of money by Icelandic standards, but certainly not enough to completely mitigate food shortage during the 1.5 years of the Haze Hardships, let alone to compensate for the loss of livestock (see table 1) and damages to pastures and buildings brought about by the eruption and the subsequent earthquakes. Compared to other Crown expenditures, these relief costs are actually quite modest. For example, in the early 1780ies, the Crown had funded 3 new trade companies, partly with capital from private share holders. When these companies went more or less bankrupt after the end of the American war of Independence, the Crown decided to compensate the shareholders for their lost capital and non-forthcoming profits by paying them 7.8 million ríkisdalir over the next years, 100 times as much as the direct aid for Iceland (Gunnarsson, 1983, p.141). Another, albeit trifling, expenditure may illustrate royal priorities. In normal years, the Crown imported 50 falcons from Iceland, but in early 1785 it was feared that no oxen could be purchased there to feed the falcons during the journey to Denmark. It was thus decided to limit the import to 30 falcons and send 20 living oxen to Iceland, to feed not the starving Icelanders but the royal falcons. The additional costs (including rebuilding the falcon ship to transport the oxen) were estimated to be 1896 ríkisdalir (Stephensen \& Sigurðsson, 1854, vol. 5, p. 128-129). These two examples suggest that, given the will, the Danish Crown could have afforded to spend more to save its Icelandic subjects from starvation.

The Danish reaction the Laki eruption has been criticised both by contemporary and later authors, especially by 19th century Icelandic nationalists who considered it a prime example of harmful Danish influence on their island (Gun- 
narsson, 1984; Oslund, 2011, Ch. 1). However, large-scale government relief was by no means the obvious reaction to famine in earlier centuries (Gunnarsson, 1980); this not only holds before the Laki eruption, but also 65 years later, e.g. during the Irish potato famine 1845-49. During that episode, initial (costly but insufficient) relief schemes were gradually abandoned for fear of disturbing the market. Unlike in Iceland 1783-84, this cannot be explained by unreliable transport and troubled communication over a stormy North Atlantic, but rather by a lack of political will: In the 1840ies the 'Laissez-faire' ideology had much influence on policy and government interference was considered harmful since 'if left to the natural law of distribution, those who deserve more would obtain it' Ó Gráda 2000, p.6-7). The Laki eruption, on the other hand, took place during a relatively enlightened period in which it was considered good governance to actively foster the economic activity of a country's subjects and to mitigate famine (Gunnarsson, 1984, 1980). Thus, however insufficient, belated and clumsy the Danish aid may have been, one should acknowledge that they at least tried to help.

\subsection{A case study in disaster (mis)management?}

Why was the disaster relief not more successful? It is interesting to discuss this question from a disaster risk reduction perspective, even though this is 'unfair' in the sense that disaster risk reduction is a fairly modern concept. It should also be acknowledged that the Danish authorities worked under severe logistic constraints. Iceland was a remote dependency which most Rent

1535 Chamber members were not familiar with, although one high-placed member, Jón Eiríksson, was a native Icelander. Communication and transport to Iceland were cumbersome and expensive, the duration of a single journey was of the order of 2-3 weeks, and in winter sailing was (considered) impossible. Transport within Iceland was likewise difficult, especially after the massive loss of horses.

The first step to take measures is to detect the threatening disaster and raise alarm. Local authorities in Iceland took a long time to realise that the Laki eruption might have severe impacts beyond the area closest to the volcano. In 
particular governor Thodal lost crucial time trying to confirm information prior to writing to Copenhagen, for fear of risking a false alarm (see sect. 4.1.1). To be fair, eruptions with such widespread effects are not common in Iceland, and Thodal's residence near Reykjavík was in one of the least exposed regions. The fluorine poisoning of livestock had not fully manifested itself in late summer 1783, although severe withering of grass had been observed throughout most of Iceland. Foreseeing the magnitude of the famine was thus difficult (and remains a difficult issue today, e.g. Hillier \& Dempsey (2012)). However, already before before Thodal's report came in, the Danish government reacted to the vague letter by merchant Sünckenberg and decided to sent a ship to Iceland - a considerable expenditure.

One important problem was undoubtedly communication troubles. When the full extent of the famine became obvious in the course of the winter, Iceland had no means to communicate with the outside world. A cautious government could have stationed a postal ship on the island each winter to be ready to sail in spring (see sect. 3.2.4). This way, the news of the famine could have reached Copenhagen about 3 months earlier in 1784, thus significantly enhancing the time window for action before the next winter. Even in summer, sailing to Iceland could be dangerous: The ship carrying orders concerning export bans got shipwrecked in August 1784. Of course, this was partly bad luck, but it was well known that the coast of Iceland was dangerous, so it would only have been prudent to send spare copies of the letters with each of the four ships sent to Iceland in late summer 1784. In other words, communication lines were not only long, but also lacked resilience, and the government did not take into account the possibility of accidents. Of course, the loss of the letters would not have had such ill consequences if Thodal - who by summer 1784 must have been aware of the grave situation in wide parts of the country - had taken more initiative and banned the fish export on his own account.

Communication troubles can be mitigated by other measures. One approach could be to have competent local representatives and to give them wide discretion to implement measures on their own. However, the top-down administra- 
tive system of absolutist Denmark rather stifled initiative. Both local officials ests. The most striking one is the multitude of roles of the trade company. Being the only organisation providing transport to Iceland, and the only owner of significant food stores on the island (at least between the fishing season in spring and the departure of the trade ships in summer), it was the instrument 

instead of acting decisively based on a plausible worst-case scenario, valuable months were spilled waiting for the return of the exploration ship and sending repeated requests to the Icelandic officials in the region nearby the Lakagígar for careful surveys of population, fugitives, livestock etc. In the words of Jón

through which the government could administer relief. At the same time, the trade company was a commercial enterprise, and both the shareholders (including the Crown) and the employees in Iceland expected to make profit from it. On the Copenhagen end, the Crown could, if it wished, override the shareholders' economic interests and decree that unprofitable rescue actions be carried out. However, the trade representatives in Iceland had a strong financial incentive to export as much from the island as they could, and thus to oppose any attempt by Icelandic officials to ban export. They also refused in some cases to put their large fishing vessels at the disposal of the governor for transporting foodstuff, possibly because they considered fishing more profitable. Maybe the central government did not foresee this problem; at least no reference regarding financial compensation is made in the order of July 21st, 1784 (Stephensen \& Sigurðsson, 1854, vol. 5, p.99-100), which (unsuccessfully) ordered that local tradesmen should 'provide their Hukkerter [fishing vessels] to transport fish and other foodstuff from one district to the other' (see sect. 4.2.3).

Finally, while the Danish government was willing to take significant action when confronted with definite bad news, it proved unwilling to do so in view of incomplete information. For example, given the disturbing, but unclear news that had reached Copenhagen by winter 1783/84, the government could have chosen for a 'least regret' option and send a substantial additional amount of grain to Iceland in early spring, even while not being sure whether it would be needed. Of course, this would have been costly in the short run, but if the situation had turned out less serious, the surplus grain could have been stored and less been sent in 1785 . The extra cost of sending too much grain in the absence of famine should have appeared much less severe then the loss of human life brought about by not sending the grain in the presence of famine. But Steingrímsson, who as dean was co-responsible for gathering this information, 
'These [census lists] could hardly be expected to make sense or to agree, as people were constantly moving back and forth and some dying' (Steingrímsson, $1788 / 1998$, p. 86). In any way, collecting information in the large, thinly populated Iceland was a tedious business, and the data could be shipped to ${ }_{1640}$ Copenhagen only with the ships departing in autumn, so that they would be acted upon only in the next year. In spring 1785, renewed requests for a careful survey of livestock and human population were sent to the whole of Iceland, partly to assess which farms were in need of assistance to buy livestock. From many districts, this information was delivered only in 1786. In short, it seems that the Danish government was so afraid to incur aid expenditures that might later prove unnecessary, that it preferred to delay action by a year or more and risk that the aid might come too late to do any good.

If one tries to find one single expression describing the shortcoming of the government response, it is undue optimism. The Danish officials hoped that the effects of the eruption would not be too bad, trusted that information from and its own orders to Iceland would be transmitted smoothly, that all (sometimes unclear) orders would be carried out immediately and effectively, with officials and trade representatives functioning perfectly without frictions such as competing interests. Maybe a more efficient aid could have been accomplished if

1655 the officials had constantly asked themselves: How can this measure go wrong - and what can be done to mitigate potential failure? But this would have required much foresight, imagination, and an intimate knowledge of the local geographical and societal situation.

\section{Funding:}

This research did not receive any specific grant from funding agencies in the public, commercial, or not-for-profit sectors.

\section{References}

Agnarsdóttir, A. (1992). Scottish plans for the annexation of Iceland 1785-1813. Northern Studies, 29, 83-91. 
D'Alessandro, W. (2006). Human fluorosis related to volcanic activity: A re-

\ view. Transactions on Biomedicine and Health, 10, 21-30. doi 10.2495/ ET0X060031.

D'Arrigo, R., Seager, R., Smerdon, J. E., LeGrande, A. N., \& Cook, E. R. 1690 (2011). The anomalous winter of 1783-1784: Was the Laki eruption or an analog of the 2009-2010 winter to blame? Geophys. Res. Lett., 38, L05706. doi $10.1029 / 2011$ GL046696. 
Durand, M., \& Grattan, J. (1999). Extensive respiratory health effects of volcanogenic dry fog in 1783 inferred from European documentary sources.

¿ Environmental Geochemistry and Health, 21, 371-376. doi:10.1023/A: 1006700921208 .

Eggertsson, T. (1996). No experiments, monumental disasters: Why it took a thousand years to develop a specialized fishing industry in Iceland. Journal of

\. Economic Behavior \& Organization, 30, 1-23. doi:10.1016/S0167-2681(96)

1700 $00839-6$

Eggertsson, T. (1998). Sources of risk, institutions for survival, and a game against nature in premodern Iceland. Explorations in Economic History, 35(1), 1-30. doi:10.1006/exeh.1997.0686

Eirìsson, J. (1984). Notes on the Haze Hardships (Icelandic with English abstr.). In G. A. Gunnlaugsson, G. M. Guðbergsson, S. Pórarinsson, S. Rafnsson, \& P. Einarsson (Eds.), Skaftáreldar 1783-84: ritgerðir og heimildir (The Laki eruption 1783-84: articles and sources) (pp. 423-435). Reykjavík: Mál og Menning.

Ferguson, P. (2018). Post-growth Politics. A Critical Theoretical and Policy Framework for Decarbonisation. Cham, Switzerland: Springer Nature.

Finnsson, H. (1796). Um mannfækkun í hallærum (decimation of the population in Iceland due to famines, in Icelandic). Rit pess konunglega íslenska lordómslistafélags, XIV, 30-226.

Friðriksson, S. (1972). Grass and grass utilization in Iceland. Ecology, 53, $1715 \quad 787-797$.

Gestsdóttir, H., Baxter, P., \& Gisladóttir, G. (2006). Fluorine poisoning in victims of the 1783-84 eruption of the Laki fissure, Iceland. Fornleifastofnun Íslands, 53, 787-797. 
Grattan, J., \& Brayshay, M. (1996). An amazing and portentous summer: environmental and social responses in Britain to the 1783 eruption of an Iceland volcano. The Geographical Journal, 161, 125-134.

Grattan, J., Durand, M., \& Taylor, S. (2003). Illness and elevated human mortality in Europe coincident with the Laki fissure eruption. In Volcanic Degassing (pp. 401-414). London: Geological Society Special Publications 213. doi:10.1144/GSL.SP. 2003.213.01.24.

Grattan, J., Rabartin, R., Self, S., \& Thordarson, T. (2005). Volcanic air pollution and mortality in France 1783-84. Comptes Rendus Geosciences, 337, 641-651. doi:10.1016/j.crte.2005.01.013.

Grattan, J., \& Sadler, J. (1999). Regional warming of the lower atmosphere in the wake of volcanic eruptions: the role of the Laki fissure eruption in the hot summer of 1783. Geological Society, London, Special Publications, 161, 161-171. doi:10.1144/GSL.SP.1999.161.01.11.

Guðbergsson, G. M., \& Theodórsson, T. (1984). Áhrif Skaftárelda á byggð og mannfjölda í Leiðvallahreppi og Kleifahreppi (consequences of the Laki eruption on settlement and population numbers in Leiðvallahreppur and Kleifahreppur, Icelandic with English abstr.). In G. A. Gunnlaugsson, G. M. Guðbergsson, S. Pórarinsson, S. Rafnsson, \& P. Einarsson (Eds.), Skaftáreldar 1783-84: ritgerðir og heimildir (The Laki eruption 1783-84: articles and sources) (pp. 99-118). Reykjavík: Mál og Menning.

Guðjónsson, S. P. (2010). Íslenskir annálar og aðrar gamlar veðurheimildir (icelandic annals and other old weather sources, in Icelandic),

\. URL: https://www.vedur.is/media/vedurstofan/utgafa/hlidarefni/ annalar_sig-th.pdf.

Guðmundsson, L. (1783a). Letter to governor Thodal, July 26th, 1783 (in dan1745 ish). In G. A. Gunnlaugsson, G. M. Guðbergsson, S. Pórarinsson, S. Rafnsson, \& P. Einarsson (Eds.), Skaftáreldar 1783-84: ritgerðir og heimildir (The Laki 
eruption 1783-84: articles and sources) (pp. 276-278). Reykjavík: Mál og Menning.

Guðmundsson, L. (1783b). Letter to the Rent Chamber, August 2nd, 1783 (in danish). In G. A. Gunnlaugsson, G. M. Guðbergsson, S. Pórarinsson, S. Rafnsson, \& P. Einarsson (Eds.), Skaftáreldar 1783-84: ritgerðir og heimildir (The Laki eruption 1783-84: articles and sources) (pp. 283-276). Reykjavík: Mál og Menning.

Gunnarsson, G. (1980). A study of causal relations in climate and 1755

1] history: With an emphasis on the Icelandic experience. Lund University, . URL: https://books.google.it/booksid=4Rk_AQAAMAAJ\&

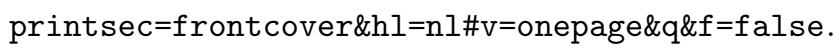

Gunnarsson, G. (1983). Monopoly trade and economic stagnation. studies in the foreign trade of Iceland,1602-1787. PhD thesis at Lund University,

. URL: https://babel.hathitrust.org/cgi/pt?id=uc1.b3524053\&view= 1 up\&seq $=6$

Gunnarsson, G. (1984). Voru Móðuharðindin af manna völdum? (were the Haze Hardships caused by men?, Icelandic with English abstr.). In G. A. Gunnlaugsson, G. M. Guðbergsson, S. Pórarinsson, S. Rafnsson, \& P. Einarsson (Eds.), Skaftáreldar 1783-84: ritgerðir og heimildir (The Laki eruption 1783-84: articles and sources) (pp. 235-242). Reykjavík: Mál og Menning.

Gunnlaugsson, G. Á. (1984a). Fólksflótti úr Vestur-Skaftafellssýslu í kjölfar Skaftárelda (emigration from Vestur-Skaftárfellssýsla following the Laki eruption, Icelandic with English abstr.). In G. A. Gunnlaugsson, G. M. Guðbergsson, S. Pórarinsson, S. Rafnsson, \& P. Einarsson (Eds.), Skaftáreldar 1783-84: ritgerðir og heimildir (The Laki eruption 1783-84: articles and sources) (pp. 119-128). Reykjavík: Mál og Menning.

Gunnlaugsson, G. Á. (1984b). Viðbrögð stjórnvalda í Kaupmannahöfn við skaftáreldum (reaction of the central government in Copenhagen during the 
Laki eruption, Icelandic with English abstr.). In G. A. Gunnlaugsson, G. M. Guðbergsson, S. Pórarinsson, S. Rafnsson, \& P. Einarsson (Eds.), Skaftáreldar 1783-84: ritgerðir og heimildir (The Laki eruption 1783-84: articles and sources) (pp. 119-128). Reykjavík: Mál og Menning.

Gunnlaugsson, G. Á., \& Rafnsson, S. (1984). Heimildir til sögu Skaftáreldanna og Móðuharðdinda (sources for the history of the Laki eruption and the Haze Hardships, Icelandic and Danish). In G. A. Gunnlaugsson, G. M. Guðbergsson, S. Pórarinsson, S. Rafnsson, \& P. Einarsson (Eds.), Skaftáreldar 1783-84: ritgerðir og heimildir (The Laki eruption 1783-84: articles and sources) (pp. 265-435). Reykjavík: Mál og Menning.

1785 Gupta, S. K., Gupta, R., Seth, A., \& Gupta, A. (1996). Reversal of fluorosis in 口 children. Pediatrics International, 38, 513-519. doi 10.1111/j.1442-200X. 1996.tb03536.x.

Halldórsson, E. (2013). Volcanic air pollution and mortality in France 1783-

п 84. MA thesis, Vienna,. URL: https://skemman.is/handle/1946/17205? locale=en

Hambrecht, G. (2009). Zooarchaeology and the archaeology of early modern Iceland. Journal of the North Atlantic, 1, 3-22. doi 10.3721/037.002.s104.

Hansell, A., \& Oppenheimer, C. (2004). Health hazards from volcanic gases: A systematic literature review. Archives of Environmental Health, 59(12), 628-639. doi:10.1080/00039890409602947.

Highwood, E. J., \& Stevenson, D. S. (2003). Atmospheric impact of the 17831784 Laki eruption: Part II climatic effect of sulphate aerosol. Atmos. Chem. Phys., 3(4), 1177-1189. doi 10.5194/acp-3-1177-2003.

Hillier, D., \& Dempsey, H. (2012). A dangerous delay. The cost of late response to early warnings in the 2011 drought in the Horn of Africa. Oxfam Policy and Practice: Agriculture, . 
Hálfdanarson, G. (1984). Mannfall í M';oðuharðindin (human mortality during the Haze Hardships, Icelandic with English abstr.). In G. A. Gunnlaugsson, G. M. Guðbergsson, S. Pórarinsson, S. Rafnsson, \& P. Einarsson (Eds.), Skaftáreldar 1783-84: ritgerðir og heimildir (The Laki eruption 1783-84: articles and sources) (pp. 139-162). Reykjavík: Mál og Menning.

International Volcanic Health Hazard Network (IVHHN) (). Volcanic gases 口 and aerosols guidelines, . URL: ttps://www.ivhhn.org/images/pdf/gas_ guidelines.pdf.

Iwasawa, S., Kikuchi, Y., Nishiwaki, Y., Nakano, M., Michikawa, T., Tsuboi, T., Tanaka, S., Uemura, T., Ishigami, A., Nakashima, H., Takebayashi, T., Adachi, M., Morikawa, A., Maruyama, K., Kudo, S., Uchiyama, I., \& Omae, K. (2009). Effects of SO2 on respiratory system of adult Miyakejima resident 2 years after returning to the island. Journal of Occupational Health, 51(1), 38-47. doi:10.1539/joh.L8075.

Jónsson, G. (2009). Scandinavian economic history review, . 46(1), 24-41.

Karlsson, G. (2000). The history of Iceland. Minneapolis: Univ Of Minnesota Press.

Kochi, T., Iwasawa, S., Nakano, M., Tsuboi, T., Tanaka, S., Kitamura, H., Wilson, D. J., Takebayashi, T., \& Omae, K. (2017). Influence of sulfur dioxide on the respiratory system of Miyakejima adult residents 6 years after returning to the island. Journal of Occupational Health, 59(4), 313-326. doi 10.1539/ joh.16-0256-0A.

Magnússon, S. G. (2010). Wasteland with Words. London: Reaktion Books.

प "vog"-related air quality in Hilo, Hawai'i. EnvironRes, 95, 11-19. doi 10. 1016/S0013-9351(03)00122-1.

Ó Gráda, C. (2000). Black '47 and Beyond: The Great Irish Famine in History, Economy, and Memory. New Jersey: Princeton University Press. 
Ó Gráda, C. (2007). Making famine history. Journal of Economic Literature, 45(1), 5-38. doi:10.1257/jel.45.1.5

Ó Gráda, C. (2009). Famine - a short history. New Jersey: Princeton University Press.

Ogilvie, A., \& Jónsdóttir, I. (2000). Sea ice, climate, and Icelandic fisheries 1835 in the eighteenth and nineteenth centuries. Arctic, 53(4), 383-394. doi 10. 14430/arctic869.

Ogilvie, A., \& Jónsson, T. (2001). 'Little Ice Age' research: A perspective from Iceland. Climatic Change, 48, 9-52. doi 10.1023/A:1005625729889.

Oman, L., Robock, A., Stenchikov, G., \& Thordarson, T. (2006a). High-latitude eruptions cast shadow over the African monsoon and the flow of the Nile. Geophys. Res. Lett., 33, L18711. doi:10.1029/2006GL027665.

Oman, L., Robock, A., Stenchikov, G., Thordarson, T., Koch, D., Shindell, D., \& Gao, C. (2006b). Modeling the distribution of the volcanic aerosol cloud from the 1783-1784 Laki eruption. J. Geophys. Res, 111, D12209. doi:10.1029/2005JD006899.

Oslund, K. (2004). Nature in league with man: Conceptualising and transforming the natural world in eighteenth-century Scandinavia. Environment and History, 10(3), 305-325. doi:10.1257/jel.45.1.5.

Oslund, K. (2011). Iceland imagined. Nature, Culture and Story-Telling in the North Atlantic. Seattle and London: Washington University Press.

Pausata, F., Karamperidou, C., Caballero, R., \& Battisti, D. (2011). ENSO response to high-latitude volcanic eruptions in the Northern Hemisphere: the

口 role of the initial conditions. Geophys. Res. Lett, 43(16), 8694-8702. doi 10. 1002/2016GL069575.

1855 Pratusha, N., Banji, O., Banji, D., Ragini, M., \& Pavani, B. (2011). Fluorine toxicity - a harsh reality. IRJP, 2(4), 79-85. 
Pétursson, G., Pálsson, A., \& Georgsson, G. (1984). Um eituráhrif af völdum Skaftárelda' (on the poisoning effects of the Laki eruption, in Icelandic with English abstr.). In G. A. Gunnlaugsson, G. M. Guðbergsson, S. Pórarinsson, S. Rafnsson, \& P. Einarsson (Eds.), Skaftáreldar 1783-84: ritgerðir og heimildir (The Laki eruption 1783-84: articles and sources) (pp. 163-178). Reykjavík: Mál og Menning.

Rafnsson, S. (1984a). Búfé og byggð við lok skaftárelda og móðuharðinda’ (Livestock and settlement at the end of the Laki eruption and Haze Hardships, Icelandic with English abstr.). In G. A. Gunnlaugsson, G. M. Guðbergsson, S. Pórarinsson, S. Rafnsson, \& P. Einarsson (Eds.), Skaftáreldar 1783-84: ritgerðir og heimildir (The Laki eruption 1783-84: articles and sources) (pp. 163-178). Reykjavík: Mál og Menning.

Rafnsson, S. (1984b). Um eldritin 1783-1788 (on the descriptions of the eruption 1783-1788, Icelandic with English abstr.). In G. A. Gunnlaugsson, G. M. Guðbergsson, S. Pórarinsson, S. Rafnsson, \& P. Einarsson (Eds.), Skaftáreldar 1783-84: ritgerðir og heimildir (The Laki eruption 1783-84: articles and sources) (pp. 243-264). Reykjavík: Mál og Menning.

Rogers, R. (2012). The fungal pharmacy: The Complete Guide to Medicinal Mushrooms and Lichens of North America. Berkeley: North Atlantic Books.

Roholm, K. (1937). Fluorine Intoxication, A Clinical-Hygienic Study with a review of the literature and some experimental investigations. Copenhagen: Nyt Nordisk Forlag.

Schmidt, A., Carslaw, K. S., Mann, G., Wilson, M., Breider, T., Pickering, S., \& Thordarson, T. (2010). The impact of the 1783-1784 AD Laki eruption on global aerosol formation processes and cloud condensation nuclei. Atmos. Chem. Phys, 10(13), 6025-6041. doi:10.5194/acp-10-6025-2010.

Schmidt, A., Ostro, B., Carslaw, K., Wilson, M., Thordarson, T., Mann, G., \& Simmons, A. (2011). Excess mortality in Europe following a future Laki- 
$\mathbf{1 8 8 5}_{\square}$ style icelandic eruption. PNAS, 108(38), 15710-15715. doi:10.1073/pnas. 1108569108

Sierra-Vargas, M., Vargas-Dominguez, C., Bobadilla-Lozoya, K., \& AztatziAguilar, O. (2018). Health impact of volcanic emissions. In G. Aiello (Ed.), Volcanoes - Geological and Geophysical Setting, Theoretical Aspects and Numerical Modeling, Applications to Industry and Their Impact on the Hu\ man Health (pp. 263-284). London: IntechOpen. doi:10.5772/intechopen. 73283.

Sigurdarson, B., \& Pálsson, P. (1957). The eruption of hekla 1947-48 - fluorosis of farm animals during the hekla eruption of 1947-1948. Soc. Sci. Isl., Spec. Publ., 3, 1-12.

Steingrímsson, J. (1783). Lítið ágrip um nýja eldsuppkomu í vestaraparta Skaftafellssýslu og pess verkarnir sem framkomnar eru (A little summary on the new firy outburst in the western part of Skaftafellsýsla and the consequences thereof, in Icelandic.). In G. A. Gunnlaugsson, G. M. Guðbergsson, S. Pórarinsson, S. Rafnsson, \& P. Einarsson (Eds.), Skaftáreldar 1783-84: ritgerðir og heimildir (The Laki eruption 1783-84: articles and sources) (pp. 272-274). Reykjavík: Mál og Menning.

Steingrimsson, J. (1788/1998). The fires of the earth. The Laki eruption of 1783-1784. Reykjavík: University of Iceland Press.

Steingrímsson, J. (1791/2002). A very present help in trouble. The autobiography of the fire-priest. New York: Peter Lang Publishing, Inc.

Stephensen, M. (1785). Kort Beskrivelse over den nye Vulcans Ildsprudning $i$ Vester-Skaptefields-Syssel paa Island $i$ Aaret 1783 (Short description of the new volcanic eruption in Vestur-Skaftafellssýsla on Iceland in the year 1910 \1783, in Danish). Copenhagen. URL: https://archive.org/details/ KortBeskrivelseo000255771v0MagnReyk/page/n5. 
Stephensen, M. (1888). Autobiographia drs. magnúsar stephensens, in icelandic). In Tímarit Hins islenzka bókmentafélags. Copenhagen. URL: http://timarit.is/view_page_init.jsp?pageId=2317831.

Stephensen, Ó. (1783). Extract from a letter to jón eiríksson of the rent chamber, august 16th, 1783 (in Icelandic). In G. A. Gunnlaugsson, G. M. Guðbergsson, S. Pórarinsson, S. Rafnsson, \& P. Einarsson (Eds.), Skaftáreldar 1783-84: ritgerðir og heimildir (The Laki eruption 1783-84: articles and sources) (p. 279). Reykjavík: Mál og Menning.

Stephensen, O., \& Sigurðsson, J. (1854). Lovsamling for Island, indeholdende Udvalg af de vigtigste celdre og nyere Love og Anordninger, Resolutioner, Instructionere og Reglementer, Althingsdomme og Vedtcegter, Collegial-Breve, Fundatser og Gavebreve, samt andre Aktestykker, til Oplysning um Islands Retsforhold og Administration i aeldre of nyere Tider (Law collection for Iceland, containing a selection of the most important elder and newer laws and orders, resolutions, instructions and regulations, Althing verdicts and by-laws, council letters, grants and endowment letters, as well as other documents, for information on Iceland's law system and administration in elder and newer times, in Danish). Copenhagen. URL: https://baekur .is/bok/000195669/ Lovsamling_for.

Stevenson, D. S., Johnson, C. E., Highwood, E. J., Gauci, V., Collins, W. J., \& Derwent, R. G. (2003). Atmospheric impact of the 1783-1784 Laki eruption: \ Part I chemistry modelling. Atmos. Chem. Phys., 3(3), 487-507. doi:10. $5194 / \mathrm{acp}-3-487-2003$.

Svanberg, I., \& Ægisson, S. (2012). Edible wild plant use in the Faroe Islands and Iceland. Acta Soc Bot Pol, 81(4), 233-238. doi 10.5586/asbp.2012.035

Sverrisson, A. (2002). Small boats and large ships: Social continuity and technical change in the Icelandic fisheries, 1800-1960. Technology and Culture, 43, 227-253. doi $10.1353 /$ tech.2002.0092. 
Thompson, W. J., Wallace, J. M., Jones, P. D., \& Kennedy, J. J. (2009). Identifying signatures of natural climate variability in time series of global-mean surface temperature: Methodology and insights. J.Climate, 22, 6120-6141. doi:10.1175/2009JCLI3089.1.

Thorarinsson, S. (2012). On the damage caused by volcanic eruptions with 1945 special reference to tephra and gases. In S. P.D., \& D. Grayson (Eds.), Volcanic activity and human geology (pp. 125-159). New York: Academic. doi:10.5586/asbp.2012.035.

Thordarson, T. (1995). Volatile release and atmospheric effects of basaltic fissure 口) eruptions. PhD thesis, University of Hawaii, Honolulu, . URL: http://hdl. handle.net/10125/9865

Thordarson, T., Larsen, G., Steinpórsson, S., \& Self, S. (2003). The 17831785 A.D. Laki-Grímsvötn eruptions II: Appraisal based on contemporary accounts. JÖKULL, 53, 11-48.

Thordarson, T., \& Self, S. (1993). The laki (skaftár fires) and grimsvötn erup1955 tions in 1783-1785. Bull Volcanol, 55, 233-263. doi/https://doi.org/10. 1007/BF00624353.

Thordarson, T., \& Self, S. (1996). Sulfur, chlorine and fluorine degassing and atmospheric loading by the Roza eruption. Columbia River Basalt group, washington, usa. J. Volcanol. Geotherm. Res., 74, 49-73. doi10.1016/ S0377-0273(96)00054-6.

Thordarson, T., \& Self, S. (2003). Atmospheric and environmental effects of the 1783-1784 Laki eruption: A review and reassessment. Journal of geopysical research, 108, NO. D1, 4011. doi 10.1029/2001JD002042.

Thorsteinsson, T., Jóhannsson, J., Stohl, A., \& Kristiansen, N. (2012). High 1965 levels of particulate matter in Iceland due to direct ash emissions by the Eyjafjallajökull eruption and resuspension of deposited ash. Journal of Geophysical Research, 117, B00C05. doi $10.1029 / 2011 \mathrm{JB} 008756$. 
Vasey, D. (1991). Population, agriculture, and famine: Iceland, 1784-1785. Hum Ecol, 19, 323-350. doi:10.1007/BF00888981.

1970 Vasey, D. (2009). Population regulation, ecology, and political economy in \ preindustrial Iceland. American Ethnologist, 23(2), 366-392. doi 10.1525/ ae1996.23.2.02a00100.

Witham, C., \& Oppenheimer, C. (2004). Mortality in England during the 178384 Laki craters eruption. Bulletin of Volcanology, 67, 15-26. doi 10.1007/ 1975 s00445-004-0357-7.

Zambri, B., Robock, A., M.J., M., \& Schmidt, A. (2019a). Modeling the 17831784 Laki eruption in Iceland: 1. aerosol evolution and global stratospheric circulation impacts. Journal of Geophysical Research: Atmospheres, 124(13), 6750-6769. doi:10.1029/2018JD029553.

1980 Zambri, B., Robock, A., M.J., M., \& Schmidt, A. (2019b). Modeling the 17831784 Laki eruption in Iceland: 2. climate impacts. Journal of Geophysical Research: Atmospheres, 124(13), 6770-6790. doi:10.1029/2018JD029554.

Zohori, F., \& R.M., D. (2009). Fluoride: Intake and metabolism, therapeutic and toxicological consequence. In J. Collins (Ed.), Molecular, Genetic, and

1985 Nutritional Aspects of Major and Trace Minerals (pp. 539-550). Academic Press. doi:10.1016/B978-0-12-802168-2.00044-0. 